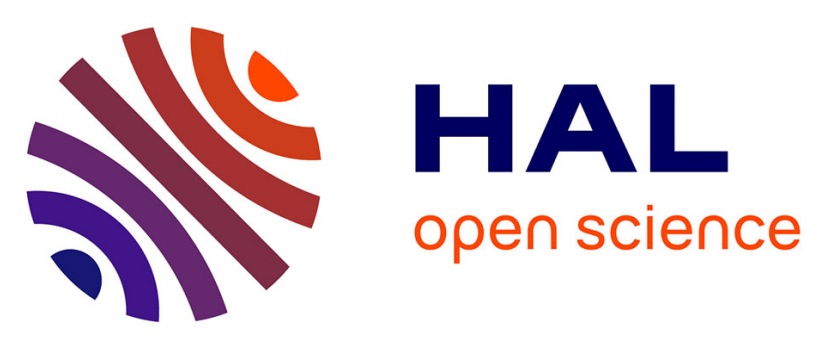

\title{
Synthesis of Ruthenium Tris-Diimine Photosensitizers Substituted by Four Methylphosphonate Anchoring Groups for Dye-Sensitized Photoelectrochemical Cell Applications
}

Nicolas Queyriaux, Emmanouil Giannoudis, Jean-François Lefebvre, Vincent Artero, Murielle Chavarot-Kerlidou

\section{To cite this version:}

Nicolas Queyriaux, Emmanouil Giannoudis, Jean-François Lefebvre, Vincent Artero, Murielle Chavarot-Kerlidou. Synthesis of Ruthenium Tris-Diimine Photosensitizers Substituted by Four Methylphosphonate Anchoring Groups for Dye-Sensitized Photoelectrochemical Cell Applications. European Journal of Inorganic Chemistry, 2019, 2019 (15 Spécial Issue), pp.2154-2161. 10.1002/ejic.201900151 . hal-02152654

\section{HAL Id: hal-02152654 \\ https://hal.science/hal-02152654}

Submitted on 18 Oct 2021

HAL is a multi-disciplinary open access archive for the deposit and dissemination of scientific research documents, whether they are published or not. The documents may come from teaching and research institutions in France or abroad, or from public or private research centers.
L'archive ouverte pluridisciplinaire HAL, est destinée au dépôt et à la diffusion de documents scientifiques de niveau recherche, publiés ou non, émanant des établissements d'enseignement et de recherche français ou étrangers, des laboratoires publics ou privés. 


\title{
Synthesis of ruthenium tris-diimine photosensitizers substituted by four methylphosphonate anchoring groups for dye-sensitized photoelectrochemical cell applications
}

\author{
Nicolas Queyriaux, ${ }^{[\mathrm{a}]}$ Emmanouil Giannoudis, ${ }^{[\mathrm{a}]}$ Jean-François Lefebvre, ${ }^{[\mathrm{a}, \mathrm{b}]}$ Vincent Artero, ${ }^{[\mathrm{a}]}$ \\ Murielle Chavarot-Kerlidou ${ }^{*}[\mathrm{a}]$

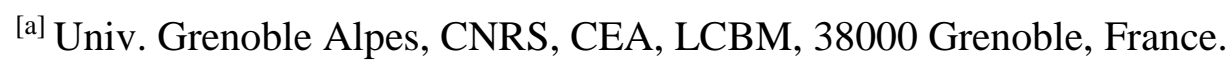 \\ ${ }^{[b]}$ Univ. Grenoble Alpes, CNRS, DPM, 38000 Grenoble, France. \\ e-mail: murielle.chavarot-kerlidou@cea.fr
}

Keywords: Ruthenium, photosensitizers, anchoring groups, photoelectrochemistry

\begin{abstract}
The design and synthesis of ruthenium tris-diimine photosensitizers appropriately functionalized to be $(i)$ anchored onto transparent conductive oxides (TCO) and (ii) covalently coupled with a water-splitting catalyst represents an important target for solar fuel production in dye-sensitized photoelectrochemical cells (DS-PECs). In this study, two different synthetic routes to prepare heteroleptic $\left[\mathrm{Ru}\left(4,4^{\prime}-\left(\mathrm{CH}_{2} \mathrm{PO}_{3} \mathrm{Et}_{2}\right)_{2}-\mathrm{bpy}\right)_{2}\left(\mathrm{~N}^{\wedge} \mathrm{N}\right)\right]\left(\mathrm{PF}_{6}\right)_{2}$ complexes are evaluated, the scope and limitations of the organometallic pathway involving half-sandwich $\eta^{6}$-arene ruthenium complexes as synthetic intermediates being especially studied. The spectroscopic and electrochemical characterizations of a series of novel structures varying by the nature of the third diimine $\mathrm{N}^{\wedge} \mathrm{N}$ ligand are reported.
\end{abstract}

\section{Introduction}

One promising chemical approach to artificial photosynthesis relies on the development of tandem dye-sensitized photoelectrochemical cells (DS-PECs) for solar fuel production. ${ }^{[1-4]}$ Tandem DS-PECs combine two photoelectrodes, $(i)$ the photoanode where the light-driven oxidation of water occurs to supply (ii) the photocathode with the required amount of electrons and protons to drive the reduction of interest. A major requirement for this approach to be effective is a stable grafting of the molecular photosensitizer/catalyst assemblies onto suitable transparent conductive oxides (TCO). The most commonly employed TCOs are $n$ type $\mathrm{TiO}_{2}$ at the photoanode and $p$-type $\mathrm{NiO}$ at the photocathode; similar grafting strategies 
have nevertheless been applied at both electrodes, drawn on the experience gained from the dye-sensitized solar cell (DSSC) technology. ${ }^{[5]}$ In that respect, the covalent grafting of carboxylic acid-substituted photosensitizers has been widely employed. Considering the specific aqueous conditions required for the DS-PECs, it is however relevant to focus on more stable anchoring systems, particularly with respect to hydrolysis. An improved stability of the grafting was observed for phosphonic acids ${ }^{[6-8]}$ covalently anchored onto oxide films compared to carboxylic acids, especially at low $\mathrm{pH}(\leq 5)$, making them anchoring groups of choice for DS-PEC applications. ${ }^{[9,10]}$ In a previous study, ${ }^{[11]}$ we established that the number of phosphonate anchoring groups present on the $\mathrm{Ru}$ photosensitizer significantly improves the grafting efficiency on nickel oxide films, the surface concentration with four phosphonate anchoring groups being roughly twice higher than the one determined with only two anchoring groups. In addition, insertion of a methylene spacer between the bipyridine (bpy) ligand and the phosphonate group electronically insulates the anchors from the complex, which could help stabilizing the excess electron density on the third diimine ligand present in the $\mathrm{Ru}$ coordination sphere, thus away from the surface. ${ }^{[11,12]}$ This warrants a better hole injection efficiency in the context of photocathode applications. Thus, bis-heteroleptic ruthenium tris-diimine photosensitizers bearing four methylphosphonate anchoring groups represent appealing targets for DS-PEC applications. Although synthetic routes were first reported in the 90's, an easy access to these complexes remains challenging due to low-yield procedures and difficult purification steps. The most straightforward route relies on the preparation of the $c i s-\mathrm{Ru}\left(4,4^{\prime}-\left(\mathrm{CH}_{2} \mathrm{PO}_{3} \mathrm{Et}_{2}\right)_{2}-\mathrm{bpy}\right)_{2} \mathrm{Cl}_{2}$ intermediate, ${ }^{[13-17]}$ whereas a second approach exploits the properties of organometallic half-sandwich $\eta^{6}$-arene ruthenium (II) complexes. ${ }^{[18-20]}$ The former procedure, called "traditional approach" below, is similar to the one previously developed for the synthesis of $c i s-\mathrm{Ru}(\mathrm{bpy})_{2} \mathrm{Cl}_{2}$, however with a yield not exceeding $32 \%$ for isolated cis- $\mathrm{Ru}\left(4,4^{\prime}-\left(\mathrm{CH}_{2} \mathrm{PO}_{3} \mathrm{Et}_{2}\right)_{2}-\mathrm{bpy}\right)_{2} \mathrm{Cl}_{2}{ }^{[14]}$ The organometallic route was first employed in 2010 by Bignozzi and coworkers, ${ }^{[18]}$ and later reexamined by the group of T.J. Meyer, ${ }^{[19,20]}$ in particular to study a novel photosensitizer-catalyst assembly anchored to $\mathrm{TiO}_{2}{ }^{[19]}$

In this study, we evaluate these two procedures for the synthesis of $\left[\mathrm{Ru}\left(4,4^{\prime}-\left(\mathrm{CH}_{2} \mathrm{PO}_{3} \mathrm{Et}_{2}\right)_{2}{ }^{-}\right.\right.$ bpy $\left.)_{2}\left(\mathrm{~N}^{\wedge} \mathrm{N}\right)\right]\left(\mathrm{PF}_{6}\right)_{2}$ complexes $\left(\mathbf{R u P}_{4}{ }^{\mathbf{O E t}}-\mathbf{N}^{\wedge} \mathbf{N}\right), \mathrm{N}^{\wedge} \mathrm{N}$ being a third diimine ligand different from bpy, if possible functionalized for an ultimate coupling with a catalytic center. The scope and limitations of the organometallic pathway involving half-sandwich $\eta^{6}$-arene ruthenium complexes as synthetic intermediates is especially studied. The spectroscopic and 
electrochemical characterizations of all novel structures are also reported and compared to the reference $\left[\mathrm{Ru}(\mathrm{bpy})_{2}\left(\mathrm{~N}^{\wedge} \mathrm{N}\right)\right]\left(\mathrm{PF}_{6}\right)_{2}$ complexes.

\section{Results and discussion}

Previous studies from the literature focused on the preparation of complexes bearing four methylphosphonic acid anchoring groups, the esters being most of the time hydrolyzed before the last purification $\operatorname{step}^{[13,14,18,20]}$ to make it easier or the phosphonic acid ligand being employed at the beginning of the procedure. ${ }^{[19]}$ In this study, we decided to isolate, purify and characterize the $\mathbf{R u P}_{4}{ }^{\mathbf{O E t}}-\mathbf{N}^{\wedge} \mathbf{N}$ complexes under their phosphonate ester form, in order to warrant good solubility in organic media allowing further synthetic steps on the $\mathrm{N}^{\wedge} \mathrm{N}$ ligand. In addition to the reference 2,2'-bipyridine (bpy) ligand, we selected 1,10-phenantroline (phen) and phen-substituted derivatives, namely 5-amino-1,10-phenantroline (phenamine), dipyrido[3,2-a:2',3'-c]phenazine (dppz), 1,10-phenantroline-5,6-dione (phendione) and 2-(4ethynylphenyl)-1H-imidazo[4,5-f][1,10]phenanthroline (EPIP) (Figure 1). The latter allows further functionalization of the $\mathbf{R u P}_{4}{ }^{\mathbf{O E t}}-\mathbf{N}^{\wedge} \mathbf{N}$ complex by copper-catalyzed azide-alkyne cycloaddition (CuAAC). ${ }^{[21]}$
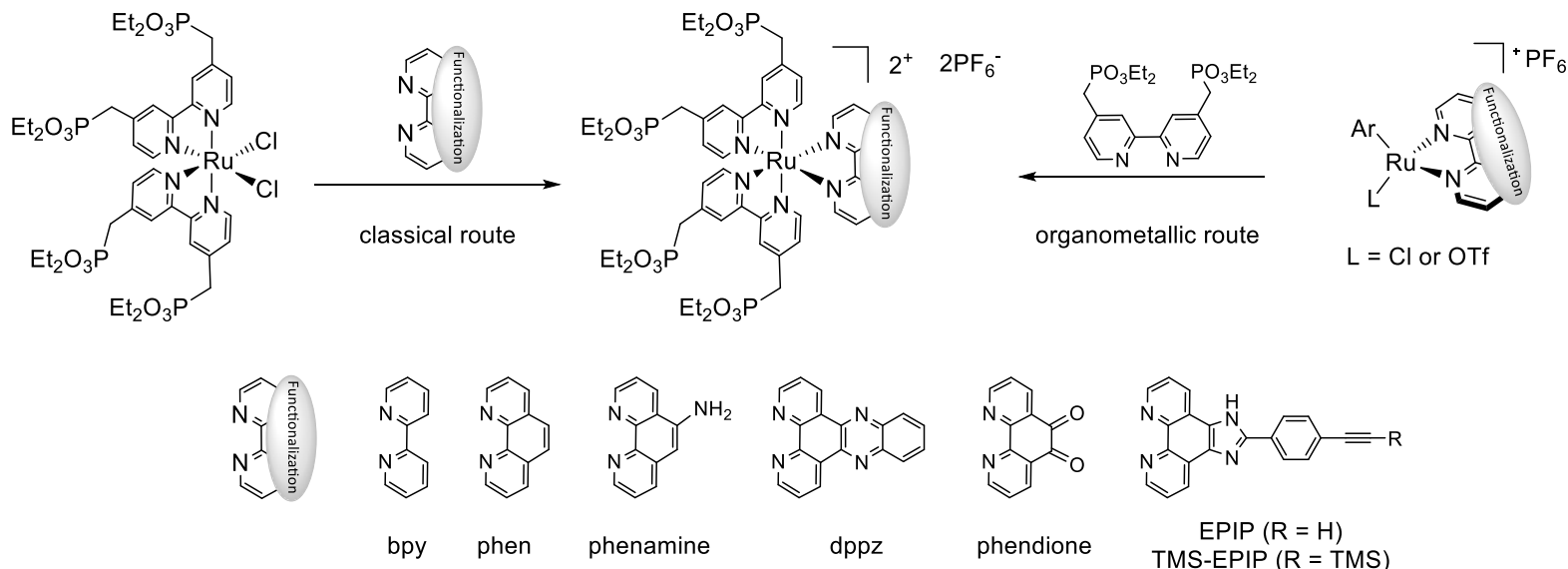

Figure 1. Schematic representation of the two synthetic routes to access the $\mathbf{R u P}_{4} \mathbf{O E t}_{\mathbf{-}} \mathbf{N}^{\wedge} \mathbf{N}$ complexes and structure of the $\mathrm{N}^{\wedge} \mathrm{N}$ ligands employed in this study.

The major difference between the two reported procedures lies in the sequential chelation order of the two $4,4^{\prime}-\left(\mathrm{CH}_{2} \mathrm{PO}_{3} \mathrm{Et}_{2}\right)_{2}$-bpy and $\mathrm{N}^{\wedge} \mathrm{N}$ to the Ru core, occurring at the last step for $\mathrm{N}^{\wedge} \mathrm{N}$ in the traditional approach against the first step in the organometallic route (Figure 1). We initially attempted to prepare our functionalized complexes by the former procedure in order to take advantage of the introduction of the functionalized ligand at the last step of the process. However, in our hands, the required cis- $\mathrm{Ru}\left(4,4^{\prime}-\left(\mathrm{CH}_{2} \mathrm{PO}_{3} \mathrm{Et}_{2}\right)_{2}-\mathrm{bpy}\right)_{2} \mathrm{Cl}_{2}$ intermediate was isolated pure in very low yields (10-20\%, using either $\mathrm{RuCl}_{3}$ or $\mathrm{Ru}(\mathrm{DMSO})_{4} \mathrm{Cl}_{2}$ as 
precursors), which was a strong limitation, as previously mentioned by T.J. Meyer. ${ }^{[20]} \mathrm{We}$ thus decided to evaluate the scope of the organometallic route in order to extend it to substituted $\mathrm{N}^{\wedge} \mathrm{N}$ ligands.

Preparation of the different organometallic $\left[\left(\eta^{6}\right.\right.$-arene $\left.) R u\left(N^{\wedge} N\right) C l\right]\left(P F_{6}\right)$ and $\left[\left(\eta^{6}\right.\right.$ arene) $\left.R u\left(N^{\wedge} N\right)(O T f)\right](O T f)$ precursors $\left(\right.$ Ar = benzene or p-cymene). The organometallic $\left(\eta^{6}-\right.$ arene) ruthenium complexes $\left[\left(\eta^{6}\right.\right.$-arene $\left.) \mathrm{Ru}\left(\mathrm{N}^{\wedge} \mathrm{N}\right) \mathrm{Cl}\right]\left(\mathrm{PF}_{6}\right)$ were readily prepared by reacting the dinuclear $\left[\left(\eta^{6} \text {-arene }\right) \mathrm{RuCl}_{2}\right]_{2}$ precursor (benzene or $p$-cymene) with two equivalents of substituted diimine $\mathrm{N}^{\wedge} \mathrm{N}$ ligands under classical thermal conditions. Protection of the EPIP ligand by a trimethylsilyl group (TMS) proved to be mandatory to avoid alkyne coordination to the $\mathrm{Ru}$ center or formation of a Ru-alkynyl ${ }^{[22]}$ complexes. Overall, the $\left[\left(\eta^{6}-\right.\right.$ arene) $\left.\mathrm{Ru}\left(\mathrm{N}^{\wedge} \mathrm{N}\right) \mathrm{Cl}\right]\left(\mathrm{PF}_{6}\right)$ complexes were isolated as $\mathrm{PF}_{6}$ salts after anion metathesis, with $\geq$ $90 \%$ yields.

These complexes being relatively kinetically inert, substitution of the chloride ligand for a triflate (OTf) one was reported to facilitate thermal removal of the arene ligand and the coordination of the two $4,4^{\prime}-\left(\mathrm{CH}_{2} \mathrm{PO}_{3} \mathrm{Et}_{2}\right)_{2}$-bpy. ${ }^{[19,}{ }^{20]}$ The $\left[\left(\eta^{6}\right.\right.$-arene $\left.) \mathrm{Ru}\left(\mathrm{N}^{\wedge} \mathrm{N}\right)(\mathrm{OTf})\right](\mathrm{OTf})$ derivatives were prepared by reacting $\left[\left(\eta^{6}\right.\right.$-arene $\left.) \mathrm{Ru}\left(\mathrm{N}^{\wedge} \mathrm{N}\right) \mathrm{Cl}\right]\left(\mathrm{PF}_{6}\right)$ with triflic acid overnight at room temperature; complexes with bpy, phen or phenamine ligands were isolated with yields > $90 \%$. We however observed that alkyne hydration occurred for $\left[\left(\eta^{6}-\right.\right.$ benzene) $\mathrm{Ru}(\mathrm{TMS}-\mathrm{EPIP}) \mathrm{Cl}]\left(\mathrm{PF}_{6}\right)$ and an alternative procedure relying on the use of AgOTf to displace the chloride ligand was unsuccessful. Isolation of the triflate complex also failed for $\left[\left(\eta^{6}\right.\right.$-arene $) \mathrm{Ru}($ phendione $\left.) \mathrm{Cl}\right]\left(\mathrm{PF}_{6}\right)$ (either benzene or $p$-cymene). In the following, the TMSEPIP and the phendione complexes were tested under their chloride form for the preparation of $\mathbf{R u P} \mathbf{P}{ }^{\mathrm{OEt}}-\mathbf{N}^{\wedge} \mathbf{N}$ by the organometallic route. The $\left[\left(\eta^{6}-\right.\right.$ arene $\left.) \mathrm{Ru}(\mathrm{dppz}) \mathrm{Cl}\right]\left(\mathrm{PF}_{6}\right)$ complex proved to be insoluble in most organic solvents (except for DMSO), preventing the preparation of $\left[\mathrm{Ru}\left(4,4^{\prime}-\left(\mathrm{CH}_{2} \mathrm{PO}_{3} \mathrm{Et}_{2}\right)_{2}-\mathrm{bpy}\right)_{2}(\mathrm{dppz})\right]\left(\mathrm{PF}_{6}\right)_{2}$ by this approach.

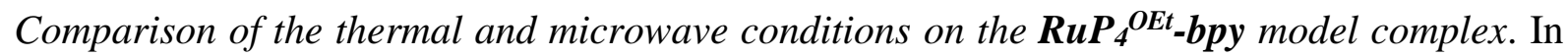
order to better understand and to optimize the synthesis of the different diethylmethylphosphonate $\mathbf{R u P}_{\mathbf{4}}{ }^{\mathbf{O E t}} \mathbf{-} \mathbf{N}^{\wedge} \mathbf{N}$ complexes, we first studied various experimental conditions on the simplest case of the series, $\mathbf{R u P}_{4} \mathbf{O E t}_{-\mathbf{b p y}}$. The reaction in refluxing ethanol between two equivalents of $4,4^{\prime}-\left(\mathrm{CH}_{2} \mathrm{PO}_{3} \mathrm{Et}_{2}\right)_{2}$-bpy and four different organometallic precursors varying by the nature of either the arene (benzene or $p$-cymene) or the anionic 
ligand (OTf or $\mathrm{Cl}$ ) was monitored by UV-vis absorption spectroscopy (Figure 2). The wavelength of $459 \mathrm{~nm}$ was selected to detect the formation of $\mathbf{R u P}_{\mathbf{4}} \mathbf{}^{\text {OEt}}$-bpy (MLCT transition $)^{[11]}$ and to determine its conversion yield. As expected, the triflate $\left[\left(\eta^{6}-\right.\right.$ arene) $\mathrm{Ru}(\mathrm{bpy})(\mathrm{OTf})](\mathrm{OTf})$ complexes are more reactive than their chloride counterparts with $30-35 \%$ conversion for the former versus $<10 \%$ for the latter. However, the conversion started to plateau after roughly 6 hours of reflux; this observation was confirmed by reacting the triflate precursors overnight at $90^{\circ} \mathrm{C}$ in a $\mathrm{H}_{2} \mathrm{O} / \mathrm{EtOH}$ mixture: isolated yields in $\mathbf{R u P} \mathbf{P} \mathbf{O E t}_{-}$ bpy didn't exceed $35 \%$ (Table 1 ).

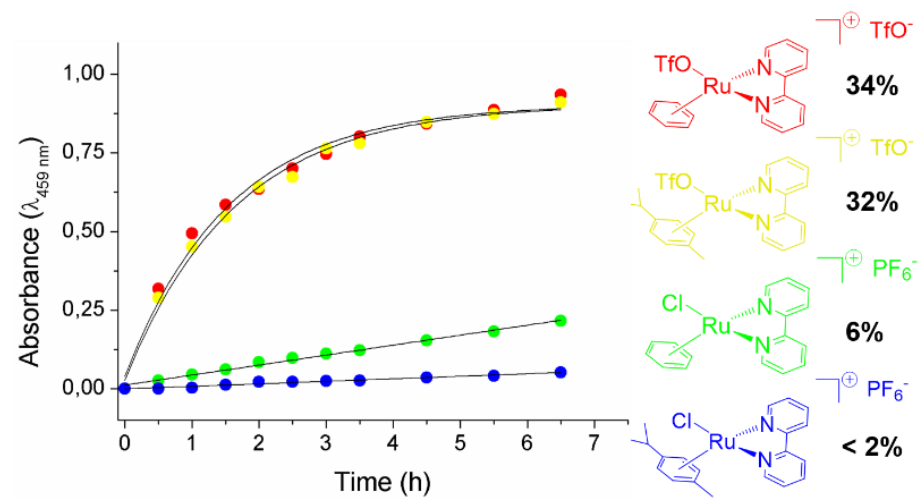

Figure 2. UV-vis monitoring (Abs @ $\lambda=459 \mathrm{~nm}$ ) of the reaction between $\left[\left(\eta^{6}-\right.\right.$ arene) $\mathrm{Ru}(\mathrm{bpy}) \mathrm{L}]\left(\mathrm{PF}_{6}\right)$ (arene $=$ benzene or $p$-cymene; $\mathrm{L}=\mathrm{Cl}$ or OTf) and 2 equivalents of 4,4'-( $\left.\mathrm{CH}_{2} \mathrm{PO}_{3} \mathrm{Et}_{2}\right)_{2}$-bpy ligand in refluxing ethanol. Right: Conversions in $\mathbf{R u P} \mathbf{P}^{\mathbf{O E t}}$-bpy calculated from the absorbance.

Table 1. Thermal activation: Isolated yields (after purification by chromatography on silica gel - see experimental section) in $\mathbf{R u P} \mathbf{4}^{\text {OEt }}$-bpy for different reaction conditions.

\begin{tabular}{|c|c|c|c|c|}
\hline Arene & $\mathbf{L}$ & Solvent, $T$, overnight & $4,4^{\prime}-\left(\mathrm{CH}_{2} \mathrm{PO}_{3} \mathrm{Et}_{2}\right)_{2}-\mathrm{bpy}$ & $\mathrm{RuP}_{4}{ }^{\text {OEt }}$-bpy \\
\hline \multirow{3}{*}{ benzene } & \multirow{2}{*}{$\mathrm{Cl}$} & \multirow{2}{*}{$\begin{array}{l}\text { 2-MeOEtOH/ } / \mathrm{H}_{2} \mathrm{O} \\
\quad(4: 1), 120^{\circ} \mathrm{C}\end{array}$} & 2 eq & $40 \%$ \\
\hline & & & $2.3 \mathrm{eq}$ & $58 \%$ \\
\hline & OTf & $\begin{array}{c}\mathrm{EtOH} / \mathrm{H}_{2} \mathrm{O}(4: 1), \\
90^{\circ} \mathrm{C}\end{array}$ & 2 eq & $35 \%$ \\
\hline \multirow{2}{*}{$p$-cymene } & $\mathrm{Cl}$ & $\begin{array}{l}\text { 2-MeOEtOH/ } / \mathrm{H}_{2} \mathrm{O} \\
\quad(4: 1), 120^{\circ} \mathrm{C}\end{array}$ & 2 eq & $<5 \%$ \\
\hline & OTf & $\begin{array}{c}\mathrm{EtOH} / \mathrm{H}_{2} \mathrm{O}(4: 1) \\
90^{\circ} \mathrm{C}\end{array}$ & 2 eq & $33 \%$ \\
\hline
\end{tabular}

The complex $\left[\left(\eta^{6}\right.\right.$-benzene $\left.) \mathrm{Ru}(\mathrm{bpy}) \mathrm{Cl}\right]\left(\mathrm{PF}_{6}\right)$ displays a very modest (6\% conversion) but still slightly higher reactivity than $\left[\left(\eta^{6}-p\right.\right.$-cymene $\left.) \mathrm{Ru}(\mathrm{bpy}) \mathrm{Cl}\right]\left(\mathrm{PF}_{6}\right)(<2 \%$ conversion) (Figure 2$)$. Taking into consideration that triflate complexes couldn't be prepared for two ligands of the series (TMS-EPIP and phendione), we decided to explore other reaction conditions in order to increase the reactivity of $\left[\left(\eta^{6}\right.\right.$-benzene $\left.) \mathrm{Ru}(\mathrm{bpy}) \mathrm{Cl}\right]\left(\mathrm{PF}_{6}\right)$. This complex being kinetically inert, higher temperatures are required for its thermal activation compared to its triflate counterpart. 
We thus switched to aqueous/organic solvent mixtures, and replaced EtOH by 2methoxyethanol (2-MeOEtOH). Results are summarized in Table 1. RuP4 ${ }^{\text {OEt }}$-bpy was isolated in $40 \%$ and $<5 \%$ yield, respectively, by refluxing overnight 2 equivalents of 4,4'$\left(\mathrm{CH}_{2} \mathrm{PO}_{3} \mathrm{Et}_{2}\right)_{2}$-bpy with either $\left[\left(\eta^{6}\right.\right.$-benzene $\left.) \mathrm{Ru}(\mathrm{bpy}) \mathrm{Cl}\right]\left(\mathrm{PF}_{6}\right)$ or $\left[\left(\eta^{6}-p\right.\right.$ cymene) $\mathrm{Ru}(\mathrm{bpy}) \mathrm{Cl}]\left(\mathrm{PF}_{6}\right)$ in a $2-\mathrm{MeOEtOH} / \mathrm{H}_{2} \mathrm{O}$ 4:1 (v:v) solvent mixture; this result is in agreement with the difference of reactivity observed for these two precursors during the course of the UV-vis monitored experiment in EtOH. Increasing the amount of 4,4'$\left(\mathrm{CH}_{2} \mathrm{PO}_{3} \mathrm{Et}_{2}\right)_{2}$-bpy from 2 to 2.3 equivalents allowed to prepare $\mathbf{R u P}_{4}{ }^{\text {OEt }}$-bpy from $\left[\left(\eta^{6}-\right.\right.$ benzene $) \mathrm{Ru}(\mathrm{bpy}) \mathrm{Cl}]\left(\mathrm{PF}_{6}\right)$ with a satisfactory yield of $58 \%$ after purification.

Microwave (MW) activation also represents an interesting alternative to thermal activation, as previously described by group of T. J. Meyer for the synthesis of $\mathbf{R u P}_{\mathbf{4}} \mathbf{O H}_{-} \mathbf{b p y}$ from $\left[\left(\eta^{6}-\right.\right.$ benzene $) \mathrm{Ru}(\mathrm{bpy})(\mathrm{OTf})](\mathrm{OTf}) .{ }^{[20]}$ This procedure is appealing as it proceeds faster and with a lower energy consumption, comparatively to the thermal activation. ${ }^{[23,24]}$ Using the previously reported experimental conditions, ${ }^{[20]} \mathbf{R u P}_{4}{ }^{\text {OEt }}$-bpy was isolated in 58 and $60 \%$ yield, using $\left[\left(\eta^{6}\right.\right.$-benzene)Ru(bpy)(OTf)](OTf) and $\left[\left(\eta^{6}-p\right.\right.$-cymene $) \operatorname{Ru}($ bpy $\left.)(\mathrm{OTf})\right](\mathrm{OTf})$ respectively, which is very close to the $62 \%$ reported yield. ${ }^{[20]}$ We then examined whether such conditions could increase the reactivity of $\left[\left(\eta^{6}\right.\right.$-arene $\left.) \mathrm{Ru}\left(\mathrm{N}^{\wedge} \mathrm{N}\right) \mathrm{Cl}\right]\left(\mathrm{PF}_{6}\right)$ precursors (Table 2). Under the conditions applied for the triflate precursors $\left(\mathrm{EtOH}, 150^{\circ} \mathrm{C}, 20 \mathrm{~min}\right)$, $\mathbf{R u P}_{4}{ }^{\text {OEt-bpy }}$ was isolated in $42 \%$ yield from $\left[\left(\eta^{6}\right.\right.$-benzene $\left.) \mathrm{Ru}(\mathrm{bpy}) \mathrm{Cl}\right]\left(\mathrm{PF}_{6}\right)$; this yield couldn't be improved by a longer reaction time (two 20 min cycles) or by adding an excess of 4,4'-( $\left.\mathrm{CH}_{2} \mathrm{PO}_{3} \mathrm{Et}_{2}\right)_{2}$-bpy ligand (2.3 instead of $\left.2 \mathrm{eq}\right)$. As previously observed, [( $\eta^{6}-p$ cymene $) \mathrm{Ru}(\mathrm{bpy}) \mathrm{Cl}]\left(\mathrm{PF}_{6}\right)$ is less reactive than $\left[\left(\eta^{6}\right.\right.$-benzene $\left.) \mathrm{Ru}(\mathrm{bpy}) \mathrm{Cl}\right]\left(\mathrm{PF}_{6}\right)$, with isolated

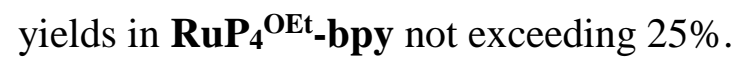

Table 2. Microwave activation: Isolated yields in $\mathbf{R u P}_{4}{ }^{\mathbf{O E t}}$-bpy for different reaction conditions $\left(\mathrm{EtOH}, 150^{\circ} \mathrm{C}\right)$.

\begin{tabular}{|c|c|c|c|c|c|}
\hline Arene & $\mathbf{L}$ & $\begin{array}{c}\text { Reaction } \\
\text { time }\end{array}$ & $4,4^{\prime}-\left(\mathrm{CH}_{2} \mathrm{PO}_{3} \mathrm{Et}_{2}\right)_{2}-\mathrm{bpy}$ & $\mathrm{RuP}_{4}{ }^{\mathrm{OEt}}$-bpy & $\begin{array}{l}\text { Monohydrolyzed } \\
\text { RuP4}^{\text {OEt }} \text {-bpy }\end{array}$ \\
\hline \multirow{5}{*}{ benzene } & OTf & $20 \mathrm{~min}$ & 2 eq & $\mathbf{5 8 \%}$ & n.d. \\
\hline & \multirow{4}{*}{$\mathrm{Cl}$} & $20 \mathrm{~min}$ & 2 eq & $42 \%$ & $14 \%$ \\
\hline & & $20 \mathrm{~min}$ & $2.3 \mathrm{eq}$ & $42 \%$ & $26 \%$ \\
\hline & & $2 \times 20 \min$ & 2 eq & $30 \%$ & n.d. \\
\hline & & $2 \times 20 \min ^{\mathrm{a}}$ & $2.3 \mathrm{eq}$ & $30 \%$ & $34 \%$ \\
\hline \multirow{2}{*}{$\begin{array}{c}p \text { - } \\
\text { cymene }\end{array}$} & OTf & $20 \mathrm{~min}$ & 2 eq & $60 \%$ & n.d. \\
\hline & $\mathrm{Cl}$ & $20 \mathrm{~min}$ & $2 \mathrm{eq}$ & $15 \%$ & $13 \%$ \\
\hline
\end{tabular}




\begin{tabular}{|l|c|c|c|c|}
\hline & $2 \times 20 \mathrm{~min}$ & $2 \mathrm{eq}$ & $20 \%$ & $14 \%$ \\
\cline { 3 - 5 } & $2 \times 20 \mathrm{~min}$ & $2.3 \mathrm{eq}$ & $25 \%$ & $22 \%$ \\
\hline
\end{tabular}

a2-methoxyethanol instead of ethanol.

It is important to underline the formation of side-products bearing partially hydrolyzed phosphonate groups. The mono-hydrolyzed derivative could be isolated with yields up to 34 $\%$ (Table 2), by chromatography on silica gel (eluted after $\mathbf{R u P} \mathbf{P}^{\text {OEt }}{ }_{\text {-bpy with } 30 \% \text { aqueous }}$ $\mathrm{KNO}_{3}(0.4 \mathrm{M})$ in $\left.\mathrm{CH}_{3} \mathrm{CN}\right)$, whereas complexes with a higher degree of hydrolysis were irreversibly adsorbed on silica. Formation of these hydrolyzed derivatives was previously mentioned in the literature ${ }^{[25]}$ and can account for the reported hydrolysis of the phosphonate ester groups before the purification. ${ }^{[13,14,18,20]}$ It is however detrimental when preparation of the complexes under their phosphonate ester form is required.

Overall, from this set of data, preparation of $\mathbf{R u P} \mathbf{P}^{\mathbf{O E t}}$-bpy can be smoothly achieved from $\left[\left(\eta^{6}\right.\right.$-arene $) \mathrm{Ru}($ bpy)(OTf) $](\mathrm{OTf})$ under microwave activation (Method B: EtOH, $150^{\circ} \mathrm{C}, 20$ min; $60 \%$ isolated yield); in addition, if the triflate precursor is not accessible, thermal conditions can be applied to $\left[\left(\right.\right.$ benzene) $\left.\mathrm{Ru}\left(\mathrm{N}^{\wedge} \mathrm{N}\right) \mathrm{Cl}\right]\left(\mathrm{PF}_{6}\right)$ (Method A: $\mathrm{MeOEtOH} / \mathrm{H}_{2} \mathrm{O}$, $120^{\circ} \mathrm{C}$, overnight; $58 \%$ isolated yield) using a 2.3 eq excess of $4,4^{\prime}-\left(\mathrm{CH}_{2} \mathrm{PO}_{3} \mathrm{Et}_{2}\right)_{2}$-bpy.

Extension to various $N^{\wedge} N$ ligands. The conditions defined above were tested for the synthesis of novel complexes, with different $\mathrm{N}^{\wedge} \mathrm{N}$ ligands. Method $\mathrm{B}$ was employed each time the triflate precursor complex could be prepared. $\mathbf{R u P}_{4}{ }^{\mathbf{O E t}}$-phen and $\mathbf{R u P}_{4}{ }^{\mathbf{O E t}}$-phenamine were in this way obtained from $\left[\left(\eta^{6}\right.\right.$-arene $) \operatorname{Ru}($ phen $\left.)(\mathrm{OTf})\right](\mathrm{OTf})$ and $\left[\left(\eta^{6}-\right.\right.$ arene) $\mathrm{Ru}($ phenamine)(OTf)](OTf), in $52 \%$ and $55 \%$ yield, respectively (Table 3 ). As already mentioned above, the lack of solubility of $\left[\left(\eta^{6}-p\right.\right.$-cymene $\left.) \mathrm{Ru}(\mathrm{dppz}) \mathrm{Cl}\right]\left(\mathrm{PF}_{6}\right)$ prevented us to test the preparation of $\mathbf{R u P}_{4}{ }^{\mathbf{O E t}} \mathbf{- d p p z}$ by the organometallic route. Synthesis of $\mathbf{R u P}_{\mathbf{4}} \mathbf{O E t}_{-}$ phendione was attempted via method $\mathrm{A}$, but proved to be unsuccessful; formation of the trishomoleptic $\left[\mathrm{Ru}\left(4,4^{\prime}-\left(\mathrm{CH}_{2} \mathrm{PO}_{3} \mathrm{Et}_{2}\right)_{2}-\mathrm{bpy}\right)_{3}\right]\left(\mathrm{PF}_{6}\right)_{2}$ complex was instead observed under these conditions, the electron-deficient phendione probably being displaced by the more electrondonating 4,4'-( $\left.\mathrm{CH}_{2} \mathrm{PO}_{3} \mathrm{Et}_{2}\right)_{2}$-bpy. Finally, method A allowed isolating RuP4 ${ }^{\text {OEt }}$-TMS-EPIP in $20 \%$ yield.

Table 3. Synthesis of various $\mathbf{R u P} \mathbf{P}^{\mathbf{O E t}}-\mathbf{N}^{\wedge} \mathbf{N}$ complexes.

\begin{tabular}{|c|c|c|c|c|c|c|}
\hline & $\mathbf{R u P}_{4}{ }^{\text {OEt }}$-phen & $\mathrm{RuP}_{4}{ }^{\text {OEt }}$-phenamine & $\mathrm{RuP}_{4}{ }^{\text {OEt }}$-phendione & $\mathrm{RuP}_{4}{ }^{\mathrm{OEt}}$-dppz & $\mathrm{RuP}_{4}{ }^{\text {OEt-TMS-EPIP }}$ & $\mathrm{RuP}_{4}{ }^{\text {OEt-EPIP }}$ \\
\hline Method A & - & - & $0 \%{ }^{\mathrm{a}}$ & - & $20 \%\left(13 \% \%^{b}\right)$ & - \\
\hline
\end{tabular}




\begin{tabular}{|c|c|c|c|c|c|c|}
\hline Method B & $52 \%$ & $55 \%$ & - & - & - & - \\
\hline $\begin{array}{c}\text { Traditional } \\
\text { approach }^{[16]}\end{array}$ & - & - & $78 \%^{\mathrm{c}}$ & $55 \%^{\mathrm{c}}$ & $20 \%^{\mathrm{c}}$ & $30 \%^{\mathrm{c}}$ \\
\hline
\end{tabular}

a- $\left[\mathrm{Ru}\left(4,4^{\prime}-\left(\mathrm{CH}_{2} \mathrm{PO}_{3} \mathrm{Et}_{2}\right)_{2} \text {-bpy }\right)_{3}\right]\left(\mathrm{PF}_{6}\right)_{2}$ was solely formed. b- Overall yield from $\mathrm{RuCl}_{3} \cdot 3 \mathrm{H}_{2} \mathrm{O}$. b- Overall yield from $\mathrm{Ru}(\mathrm{DMSO})_{4} \mathrm{Cl}_{2}$.

The synthetic limitations (poor orthogonality due to reactive organometallic intermediates, notably) observed at different stages of the organometallic route prompted us to reexamine the traditional approach. The group of S. Rau optimized it in order to prepare the phendione complex $\mathbf{R u P}_{4}{ }^{\text {OEt }}$-phendione, key to access an immobilizable RuPd dyad. ${ }^{[16]}$ Starting from $\mathrm{Ru}(\mathrm{DMSO})_{4} \mathrm{Cl}_{2}$ instead of $\mathrm{RuCl}_{3}$, the cis- $\mathrm{Ru}\left(4,4^{\prime}-\left(\mathrm{CH}_{2} \mathrm{PO}_{3} \mathrm{Et}_{2}\right)_{2}-\mathrm{bpy}\right)_{2} \mathrm{Cl}_{2}$ intermediate better described as a mixture of $\left[\right.$ cis- $\left.\mathrm{Ru}\left(4,4^{\prime}-\left(\mathrm{CH}_{2} \mathrm{PO}_{3} \mathrm{Et}_{2}\right)_{2}-\mathrm{bpy}\right)_{2} \mathrm{Cl}_{2-\mathrm{x}}(\mathrm{DMSO})_{\mathrm{x}}\right] \mathrm{Cl}_{\mathrm{x}}-$ was isolated without any purification and directly used for the last step of the process, i.e. coordination of the functionalized $\mathrm{N}^{\wedge} \mathrm{N}$ ligand. The use of $\mathrm{Ru}(\mathrm{DMSO})_{4} \mathrm{Cl}_{2}$ has been previously reported by F. Odobel and coworkers to dramatically improved the first step of the procedure for related Ru complexes. ${ }^{[25]}$ The synthesis of $\mathbf{R u P} \mathbf{4}{ }^{\text {OEt }}$-phendione, reported with a $86 \%$ crude yield, ${ }^{[16]}$ was reproduced with an overall $78 \%$ yield in our hands. Moreover, we

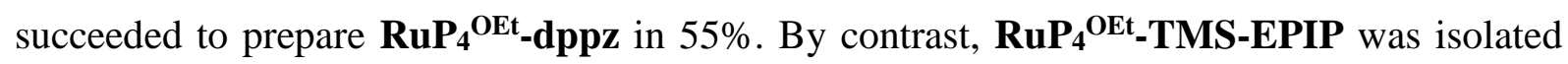
with a disappointing $10 \%$ yield, in a first attempt. It could be improved to $20 \%$ by increasing the amount of TMS-EPIP to 1.5 equivalent. Interestingly, protection of the terminal alkyne is

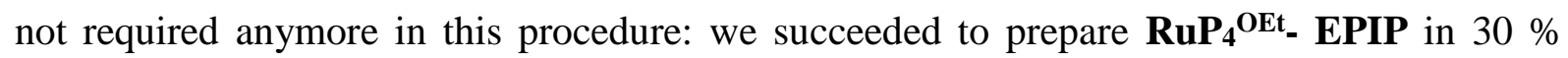
yield by directly reacting 1.5 equivalent of EPIP ligand with $\left[\right.$ cis- $\mathrm{Ru}\left(4,4^{\prime}-\left(\mathrm{CH}_{2} \mathrm{PO}_{3} \mathrm{Et}_{2}\right)_{2}-\right.$ bpy $\left.)_{2} \mathrm{Cl}_{2-\mathrm{x}}(\mathrm{DMSO})_{\mathrm{x}}\right] \mathrm{Cl}_{\mathrm{x}}$. This procedure thus proved to be more efficient and straightforward - only two steps only from $\mathrm{Ru}(\mathrm{DMSO})_{4} \mathrm{Cl}_{2}$ - compared to the organometallic route and its overall $13 \%$ yield (from $\mathrm{RuCl}_{3} .3 \mathrm{H}_{2} \mathrm{O}$ ) for $\mathbf{R u P}_{4}{ }^{\text {OEt }}$-TMS-EPIP.

Spectroscopic and redox properties of the new $\boldsymbol{R u P}_{4}{ }^{\text {oEt }}-\boldsymbol{N}^{\wedge} \boldsymbol{N}$ complexes. The UV/vis

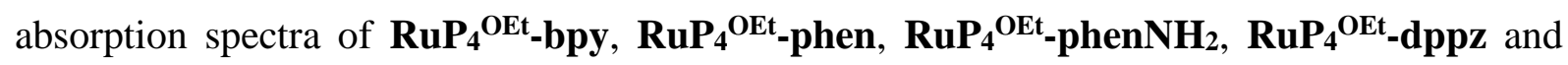
$\mathbf{R u P}_{4}{ }^{\text {OEt}}$-EPIP were recorded in acetonitrile and compared to the parent $\left[\mathrm{Ru}(\mathrm{bpy})_{2}\left(\mathrm{~N}^{\wedge} \mathrm{N}\right)\right]\left(\mathrm{PF}_{6}\right)_{2}$ compounds (Figures $\mathrm{S} 7-11$ in Supporting Information). Spectroscopic data are summarized in Table 4 . These spectra display intense ligand-centered $\pi-\pi^{*}$ absorption bands between 260 and $300 \mathrm{~nm}$; RuP4 ${ }^{\text {OEt }}$-dppz displays an additional band at $358 \mathrm{~nm}$ attributed to a dppz-centered transition. ${ }^{[26]}$ The visible part of the spectra is dominated by the classical metal-to-ligand charge-transfer (MLCT) transitions centered around 450-460 nm with a shoulder at $430 \mathrm{~nm}$. In comparison to the parent complexes, introduction of four weak 
electron-donating methyl phosphonate substituents induces a slight bathochromic shift (5 to 7 $\mathrm{nm})$ of the MLCT bands, due to stabilization of bpy-based $\pi^{*}$ orbital.

Table 4. Spectroscopic ${ }^{a}$ and redox properties ${ }^{b}$ of complexes $\mathbf{R u P}_{4}{ }^{\text {OEt }}$-bpy, $\mathbf{R u P}_{4}{ }^{\text {OEt }_{-}}$-phen,

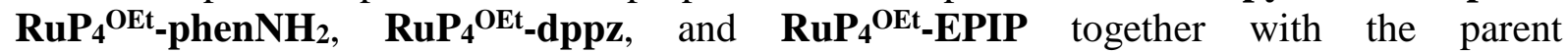
$\left[\mathrm{Ru}(\mathrm{bpy})_{3}\right]\left(\mathrm{PF}_{6}\right)_{2}, \quad\left[\mathrm{Ru}(\mathrm{bpy})_{2}(\right.$ phen $\left.)\right]\left(\mathrm{PF}_{6}\right)_{2}, \quad\left[\mathrm{Ru}(\mathrm{bpy})_{2}\left(\mathrm{phenNH}_{2}\right)\right]\left(\mathrm{PF}_{6}\right)_{2}$, $\left[\mathrm{Ru}(\mathrm{bpy})_{2}(\mathrm{dppz})\right]\left(\mathrm{PF}_{6}\right)_{2}$ and $\left[\mathrm{Ru}(\mathrm{bpy})_{2}(\mathrm{EPIP})\right]\left(\mathrm{PF}_{6}\right)_{2}$ as reference complexes.

\begin{tabular}{|c|c|c|c|c|c|c|c|}
\hline Photosensitizer & Ref & $\lambda_{\text {abs }}(\varepsilon)^{c}$ & $\boldsymbol{E}_{\mathbf{~ o x}}$ & $E_{\text {red1 }}$ & $E_{\text {red2 }}$ & $E_{\text {red3 }}$ & $E_{\text {red4 }}$ \\
\hline $\mathrm{RuP}_{4}{ }^{\text {OEt }}$-bpy & [11] & $\begin{array}{l}288(85370), \\
456(14830)\end{array}$ & +0.87 & -1.71 & -1.90 & -2.15 & - \\
\hline$\left[\mathrm{Ru}(\mathrm{bpy})_{3}\right]\left(\mathrm{PF}_{6}\right)_{2}$ & [11] & $\begin{array}{l}286(94480), \\
451(14710)\end{array}$ & +0.89 & -1.73 & -1.92 & -2.17 & - \\
\hline $\mathrm{RuP}_{4}{ }^{\mathrm{OEt}}$-phen & $\begin{array}{l}\text { this } \\
\text { work }\end{array}$ & $\begin{array}{l}264(57120), \\
289(67990), \\
455(16580)\end{array}$ & +0.87 & -1.72 & -1.90 & -2.16 & - \\
\hline$\left[\mathrm{Ru}(\mathrm{bpy})_{2}(\right.$ phen $\left.)\right]\left(\mathrm{PF}_{6}\right)_{2}$ & $\begin{array}{l}\text { this } \\
\text { work }\end{array}$ & $\begin{array}{l}264(56150), \\
286(63875), \\
449(15900)\end{array}$ & +0.88 & -1.75 & -1.94 & -2.20 & - \\
\hline $\mathrm{RuP}_{4}{ }^{\text {OEt }}$-phenNH $\mathrm{N}_{2}$ & $\begin{array}{l}\text { this } \\
\text { work }\end{array}$ & $\begin{array}{l}289(60145) \\
464(14025)\end{array}$ & +0.95 & -1.74 & -1.94 & -2.20 & - \\
\hline$\left[\mathrm{Ru}(\mathrm{bpy})_{2}\left(\mathrm{phenNH}_{2}\right)\right]\left(\mathrm{PF}_{6}\right)_{2}$ & $\begin{array}{l}\text { this } \\
\text { work }\end{array}$ & $\begin{array}{l}285(59635) \\
458(13540)\end{array}$ & +0.93 & -1.78 & -1.98 & -2.23 & - \\
\hline $\mathrm{RuP}_{4}{ }^{\text {OEt }}$-dppz & [11] & $\begin{array}{l}285 \text { (97975), } \\
368(13990), \\
457(14331)\end{array}$ & +0.88 & -1.38 & -1.72 & -1.93 & -2.34 \\
\hline$\left[\mathrm{Ru}(\mathrm{bpy})_{2}(\mathrm{dppz})\right]\left(\mathrm{PF}_{6}\right)_{2}$ & [11] & $\begin{array}{l}283(85090), \\
367(14780), \\
449(14385)\end{array}$ & +0.88 & -1.38 & -1.84 & -2.05 & -2.31 \\
\hline $\mathrm{RuP}_{4}{ }^{\text {oEt}}$-EPIP & $\begin{array}{l}\text { this } \\
\text { work }\end{array}$ & $\begin{array}{c}288(131360) \\
457(20090)\end{array}$ & +0.85 & -1.74 & -1.96 & -2.38 & - \\
\hline$\left[\mathrm{Ru}(\mathrm{bpy})_{2}(\mathrm{EPIP})\right]\left(\mathrm{PF}_{6}\right)_{2}$ & $\begin{array}{l}\text { this } \\
\text { work }\end{array}$ & $\begin{array}{c}290(106085), \\
463(19250)\end{array}$ & +0.88 & -1.78 & -2.02 & -2.39 & - \\
\hline
\end{tabular}

a. Absorption spectra were recorded in acetonitrile.

b. in $\mathrm{V}$ vs $\mathrm{Fc}^{+} / \mathrm{Fc}$. Cyclic voltammograms were recorded at a complex concentration of $1 \mathrm{mM}$ in a $0.1 \mathrm{M}$ solution of $n-\mathrm{Bu}_{4} \mathrm{NBF}_{4}$ in degassed acetonitrile and at a scan rate of $100 \mathrm{mV} . \mathrm{s}^{-1}$.

c. $\lambda_{\text {abs }}$ in $\mathrm{nm} ; \varepsilon$ in $\mathrm{L} \cdot \mathrm{mol}^{-1} \cdot \mathrm{cm}^{-1}$.

Cyclic and square wave voltammograms were recorded in degassed $0.1 \mathrm{M} n$-Bu4NBF4 solution in acetonitrile (Figures S12-16 in Supporting Information) and the redox properties of the different complexes are listed in Table 4. The quasi-reversible one-electron process 


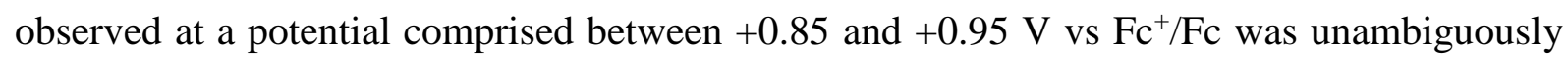
attributed to the metal-centered $\mathrm{Ru}^{\mathrm{III} / \mathrm{II}}$ oxidation, according to previous studies on related ruthenium tris-diimine complexes, ${ }^{[9,}$ 27] For all complexes, the three quasi-reversible reductions on the diimine ligands are recorded on a range of potentials varying from -1.7 to $-2.4 \mathrm{~V}$ vs $\mathrm{Fc}^{+/ 0}$. The cyclic voltammograms of $\mathbf{R u P}_{4} \mathbf{O E t}_{-\mathbf{d p p z}}$ and of the parent $\left[\mathrm{Ru}(\mathrm{bpy})_{2}(\mathrm{dppz})\right]\left(\mathrm{PF}_{6}\right)_{2}$ are characterized by the presence of an additional process at $-1.38 \mathrm{~V}$ $v s \mathrm{Fc}^{+/ 0}$, assigned to the pyrazine-based reduction of the dppz ligand. ${ }^{[28,29]}$

Overall, the introduction of four methylphosphonate anchoring groups in the coordination sphere of $\left[\mathrm{Ru}(\mathrm{bpy})_{2}\left(\mathrm{~N}^{\wedge} \mathrm{N}\right)\right]\left(\mathrm{PF}_{6}\right)_{2}$ photosensitizers does not significantly modify their properties, consistent with the electronic decoupling provided by the methylene spacer. ${ }^{[11,12]}$

\section{Conclusion}

Novel ruthenium trisdiimine photosensitizers of general formula $\left[\mathrm{Ru}\left(4,4^{\prime}-\left(\mathrm{CH}_{2} \mathrm{PO}_{3} \mathrm{Et}_{2}\right)_{2}-\right.\right.$ bpy $\left.)_{2}\left(\mathrm{~N}^{\wedge} \mathrm{N}\right)\right]\left(\mathrm{PF}_{6}\right)_{2}$, bearing four methylphosphonate anchors, were prepared by two different synthetic procedures. The scope of the organometallic procedure was first studied; some synthetic limitations are highlighted, related to the introduction of the $\mathrm{N}^{\wedge} \mathrm{N}$ ligand at the very beginning of the process. On the other hand, the traditional approach offers wider versatility, provided that the cis- $\mathrm{Ru}\left(4,4^{\prime}-\left(\mathrm{CH}_{2} \mathrm{PO}_{3} \mathrm{Et}_{2}\right)_{2}-\mathrm{bpy}\right)_{2} \mathrm{Cl}_{2}$ intermediate is used as prepared. Notably, synthesis of a novel alkyne-functionalized photosensitizer, $\left[\mathrm{Ru}\left(4,4^{\prime}-\left(\mathrm{CH}_{2} \mathrm{PO}_{3} \mathrm{Et}_{2}\right)_{2}{ }^{-}\right.\right.$ bpy $\left.)_{2}(\mathrm{EPIP})\right]\left(\mathrm{PF}_{6}\right)_{2}$, is reported. Although increasing its isolated yield remains challenging, this complex offers interesting perspectives for the immobilization of dye-catalyst assemblies onto semi-conductor surfaces. Finally, the electronic properties of these light-harvesting units were studied and proved not to be significantly altered by the introduction of four phosphonate anchors thanks to the presence of a methylene spacer, which is an important parameter for future applications in the field of DS-PECs.

\section{Experimental section}

All reagents were purchased from Sigma Aldrich or Strem and used as obtained unless otherwise stated. Reagent-grade solvents were used without further purification. The 4,4'bis(diethylphosphonomethyl)-2,2'-bipyridine ligand (4,4'-( $\left.\mathrm{CH}_{2} \mathrm{PO}_{3} \mathrm{Et}_{2}\right)_{2}$-bpy) was customsynthesized by the company Oribase Pharma, according to a previously reported procedure. ${ }^{[9]}$ The dipyrido[3,2-a:2',3'-c]phenazine (dppz), ${ }^{[29]}$ phendione, ${ }^{[30]}$ 2-(4trimethylsilylethynylphenyl)-1H-imidazo[4,5-f][1,10]phenanthroline (epip-TMS) ${ }^{[31]}$ and 2-(4ethynylphenyl)-1H-imidazo[4,5-f][1,10]phenanthroline (epip) $)^{[21]}$ ligands were prepared 
according to previously reported procedures. Spectroscopic and electrochemical characterizations of complexes $\mathbf{R u P}_{4}{ }^{\mathbf{O E t}}$-bpy and $\mathbf{R u P} \mathbf{P}_{4}{ }^{\mathbf{O E t}}$-dppz were previously reported. ${ }^{1} \mathrm{H}$ NMR experiments were carried out on a Bruker Avance $300 \mathrm{MHz}$ and the resulting spectra are referenced to the residual solvent peak and reported in relative to tetramethylsilane reference $(\delta=0 \mathrm{ppm})$. UV-vis absorption spectra were recorded either on a Shimadzu UV1800 spectrometer or on an Agilent Cary $60 \mathrm{UV}-\mathrm{Vis}$ spectrometer. ESI-MS measurements were carried out on a Thermoquest Finnigan LCQ spectrometer.

[Ru( $\eta^{6}$-benzene $\left.)_{2} \mathbf{C l}_{2}\right]_{2} .{ }^{[32]}$ A solution of $\mathrm{RuCl}_{3} .3 \mathrm{H}_{2} \mathrm{O} \quad(3 \mathrm{~g}, 11.5 \mathrm{mmol})$ and 1,4cyclohexadiene $(11 \mathrm{~mL}, 115 \mathrm{mmol})$ in absolute ethanol $(150 \mathrm{~mL})$ was heated to reflux for 8 hours. The reaction mixture was then cooled down to $-40^{\circ} \mathrm{C}$ overnight. The dark orange precipitate is finally filtrated, washed with diethyl ether and dried under vacuum to yield 2.02 $\mathrm{g}(71 \%)$ of $\left[\mathrm{Ru}\left(\eta^{6} \text {-benzene }\right)_{2} \mathrm{Cl}_{2}\right]_{2} .{ }^{1} \mathrm{H}$ NMR $\left(300 \mathrm{MHz}, \mathrm{CDCl}_{3}\right): \delta(\mathrm{ppm}) 5.71(\mathrm{~s}, 6 \mathrm{H})$.

$\left[\mathbf{R u}\left(\eta^{6}-p \text {-cymene }\right)_{2} \mathbf{C l}_{2}\right]_{2 .}{ }^{[32]}$ A solution of $\mathrm{RuCl}_{3} .3 \mathrm{H}_{2} \mathrm{O}(3 \mathrm{~g}, 11.5 \mathrm{mmol})$ and $\alpha$-phellandrene $(19 \mathrm{~mL}, 115 \mathrm{mmol})$ in absolute ethanol $(150 \mathrm{~mL})$ was heated to reflux for 8 hours. The reaction mixture was then cooled down to $-40^{\circ} \mathrm{C}$ overnight. The dark red crystalline product is finally filtrated, washed with diethyl ether and dried under vacuum to yield $3.39 \mathrm{~g} \mathrm{(96 \% )} \mathrm{of}$ $\left[\mathrm{Ru}\left(\eta^{6}-p \text {-cymene }\right)_{2} \mathrm{Cl}_{2}\right]_{2} .{ }^{1} \mathrm{H}$ NMR $\left(300 \mathrm{MHz}, \mathrm{CDCl}_{3}\right): \delta(\mathrm{ppm}) 5.47(\mathrm{~d}, 2 \mathrm{H}), 5.33(\mathrm{~d}, 2 \mathrm{H})$, 2.92 (hept., 1H), 2.15 (s, 3H), 1.27 (d, 6H).

General procedure for the synthesis of $\left[\left(\eta^{6}\right.\right.$-benzene $\left.) R u\left(N^{\wedge} N\right) C l\right]\left(P F_{6}\right)\left(N^{\wedge} N=\right.$ bpy, phen, phenamine, phendione, epip-TMS). A solution of $\left[\left(\eta^{6} \text {-benzene }\right) \mathrm{RuCl}_{2}\right]_{2}(150 \mathrm{mg}, 0.3 \mathrm{mmol})$ and $\mathrm{N}^{\wedge} \mathrm{N}$ diimine ligand $(0.6 \mathrm{mmol})$ in methanol $(50 \mathrm{~mL})$ was heated to reflux overnight. Solvent was removed under reduced pressure and the resulting precipitate dissolved in water $(5 \mathrm{~mL})$. Dropwise addition of a saturated $\mathrm{KPF}_{6}$ aqueous solution gave a dark to bright yellow solid, which was collected, washed thoroughly with water $(5 \times 10 \mathrm{~mL})$, diethyl ether $(3 \times 10$ $\mathrm{mL}$ ) and finally dried under vacuum.

[( $\eta^{6}$ - benzene)Ru(bpy)CI](PF6). Yield: $91 \% .{ }^{1} \mathrm{H}$ NMR $(300 \mathrm{MHz}, \mathrm{MeOD}): \delta(\mathrm{ppm}) 9.40(\mathrm{~d}$, $\mathrm{J}=5.6 \mathrm{~Hz}, 2 \mathrm{H}), 8.31(\mathrm{~d}, \mathrm{~J}=8.1 \mathrm{~Hz}, 2 \mathrm{H}), 8.18(\mathrm{t}, \mathrm{J}=7.8 \mathrm{~Hz}, 2 \mathrm{H}), 7.68(\mathrm{t}, \mathrm{J}=6.6 \mathrm{~Hz}, 2 \mathrm{H})$, $6.01(\mathrm{~s}, 6 \mathrm{H}) . \mathrm{ESI}-\mathrm{MS}: \mathrm{m} / \mathrm{z} 371.0\left[\mathrm{M}-\mathrm{PF}_{6}\right]^{+}$.

$\left[\left(\eta^{6}\right.\right.$-benzene)Ru(phen)CI](PF6). Yield: $93 \% .{ }^{1} \mathrm{H}$ NMR $\left(300 \mathrm{MHz}, \mathrm{CD}_{3} \mathrm{CN}\right): \delta(\mathrm{ppm}) 9.74$ $(\mathrm{d}, \mathrm{J}=5.2 \mathrm{~Hz}, 2 \mathrm{H}), 8.75(\mathrm{~d}, \mathrm{~J}=8.2 \mathrm{~Hz}, 2 \mathrm{H}), 8.14(\mathrm{~s}, 2 \mathrm{H}), 8.02(\mathrm{dd}, \mathrm{J}=8.2,5.3 \mathrm{~Hz}, 2 \mathrm{H}), 6.10$ (s, 6H). ESI-MS: m/z 395.0 [M-PF6] ${ }^{+}$. 
[( $\eta^{6}$-benzene)Ru(phenamine)CI](PF6). Yield: $94 \% .{ }^{1} \mathrm{H}$ NMR $\left(300 \mathrm{MHz}, \mathrm{CD}_{3} \mathrm{CN}\right): \delta(\mathrm{ppm})$ $9.71(\mathrm{~d}, \mathrm{~J}=5.3 \mathrm{~Hz}, 1 \mathrm{H}), 9.34(\mathrm{~d}, \mathrm{~J}=5.2 \mathrm{~Hz}, 1 \mathrm{H}), 8.73(\mathrm{~d}, \mathrm{~J}=8.5 \mathrm{~Hz}, 1 \mathrm{H}), 8.31(\mathrm{~d}, \mathrm{~J}=8.3 \mathrm{~Hz}$, 1H), 7.97 (dd, J = 8.5, 5.3 Hz, 1H), $7.76(\mathrm{dd}, \mathrm{J}=8.3,5.2 \mathrm{~Hz}, 1 \mathrm{H}), 7.05$ (s, 1H), 6.05 (s, 6H), 5.48 (s, 2H). ESI-MS: m/z $409.6\left[\mathrm{M}-\mathrm{PF}_{6}\right]^{+}$.

$\left[\left(\eta^{6}\right.\right.$ - benzene $) \mathbf{R u}($ phendione $\left.) \mathbf{C l}\right](\mathbf{P F})$. Yield: $93 \% .{ }^{1} \mathrm{H}$ NMR $\left(300 \mathrm{MHz}, \mathrm{CD}_{3} \mathrm{CN}\right): \delta(\mathrm{ppm})$ $9.81(\mathrm{dd}, \mathrm{J}=5.6,1.2 \mathrm{~Hz}, 2 \mathrm{H}), 8.65(\mathrm{dd}, \mathrm{J}=7.9,1.2 \mathrm{~Hz}, 2 \mathrm{H}), 7.99(\mathrm{dd}, \mathrm{J}=7.9,5.6 \mathrm{~Hz}, 2 \mathrm{H})$, 6.31 (s, 6H). ESI-MS: m/z $425.0\left[\mathrm{M}-\mathrm{PF}_{6}\right]^{+}$.

[( $\eta^{6}$ - benzene)Ru(TMS-EPIP)CI](PF $)$. Yield: $95 \% .{ }^{1} \mathrm{H}$ NMR (300 MHz, DMSO d6): $\delta$ (ppm) 9.97 (d, J = 5.2 Hz, 2H), 9.21 (d, J = 9.0 Hz, 2H), 8.31 (d, J = 8.3 Hz, 2H), $8.28-8.15$ $(\mathrm{m}, 2 \mathrm{H}), 7.76(\mathrm{~d}, \mathrm{~J}=8.5 \mathrm{~Hz}, 2 \mathrm{H}), 6.33(\mathrm{~s}, 6 \mathrm{H}), 0.27$ (s, 9H). ESI-MS: m/z $607.2\left[\mathrm{M}_{-\mathrm{PF}}\right]^{+}$.

General procedure for the synthesis of $\left[\left(\eta^{6}\right.\right.$-p-cymene $\left.) R u\left(N^{\wedge} N\right) C l\right]\left(P F_{6}\right)\left(N^{\wedge} N=\right.$ bpy, phen, phenamine, phendione, dppz):

A solution of $\left[\left(\eta^{6}-p \text {-cymene }\right) \mathrm{RuCl}_{2}\right]_{2}(150 \mathrm{mg}, 0.25 \mathrm{mmol})$ and $\mathrm{N}^{\wedge} \mathrm{N}$ ligand $(0.5 \mathrm{mmol})$ in methanol $(50 \mathrm{~mL})$ was heated to reflux overnight. Solvent was removed under reduced pressure and the resulting precipitate dissolved in water $(5 \mathrm{~mL})$. Dropwise addition of a saturated $\mathrm{KPF}_{6}$ aqueous solution gave a dark to bright yellow solid, which was collected, washed thoroughly with water $(5 \times 10 \mathrm{~mL})$, diethyl ether $(3 \times 10 \mathrm{~mL})$ and finally dried under vacuum.

[( $\eta^{\mathbf{6}}$-p-cymene)Ru(bpy)Cl] (PF $)$. Yield: $89 \% .{ }^{1} \mathrm{H}$ NMR $\left(300 \mathrm{MHz}, \mathrm{CD}_{3} \mathrm{CN}\right): \delta(\mathrm{ppm}) 9.32$ $(\mathrm{d}, \mathrm{J}=5.6 \mathrm{~Hz}, 2 \mathrm{H}), 8.31(\mathrm{~d}, \mathrm{~J}=8.1 \mathrm{~Hz}, 2 \mathrm{H}), 8.18(\mathrm{t}, \mathrm{J}=7.9 \mathrm{~Hz}, 2 \mathrm{H}), 7.69(\mathrm{t}, \mathrm{J}=6.6 \mathrm{~Hz}, 2 \mathrm{H})$, $5.91(\mathrm{~d}, \mathrm{~J}=6.3 \mathrm{~Hz}, 2 \mathrm{H}), 5.71(\mathrm{~d}, \mathrm{~J}=6.3 \mathrm{~Hz}, 2 \mathrm{H}), 2.65$ (hept., 1H), 2.20 (s, 3H), 1.02 (d, J = $6.9 \mathrm{~Hz}, 6 \mathrm{H}) . \mathrm{ESI}-\mathrm{MS}: \mathrm{m} / \mathrm{z} 427.1\left[\mathrm{M}-\mathrm{PF}_{6}\right]^{+}$.

[( $\eta^{6}$-p-cymene)Ru(phen)Cl] (PF6). Yield : $90 \%$. ${ }^{1} \mathrm{H}$ NMR $\left(300 \mathrm{MHz}, \mathrm{CD}_{3} \mathrm{CN}\right): \delta(\mathrm{ppm})$ $9.66(\mathrm{~d}, \mathrm{~J}=5.3 \mathrm{~Hz}, 2 \mathrm{H}), 8.75(\mathrm{~d}, \mathrm{~J}=8.3 \mathrm{~Hz}, 2 \mathrm{H}), 8.15(\mathrm{~s}, 2 \mathrm{H}), 8.03(\mathrm{dd}, \mathrm{J}=8.2,5.3 \mathrm{~Hz}, 2 \mathrm{H})$, $6.02(\mathrm{~d}, \mathrm{~J}=6.3 \mathrm{~Hz}, 2 \mathrm{H}), 5.83$ (d, J = 6.3 Hz, 2H), 2.69 (hept., 1H), 2.17 (s, 3H), 1.00 (d, J = $6.9 \mathrm{~Hz}, 6 \mathrm{H}) . \mathrm{ESI}-\mathrm{MS}: \mathrm{m} / \mathrm{z} 451.1\left[\mathrm{M}-\mathrm{PF}_{6}\right]^{+}$.

[( $\eta^{6}$-p-cymene)Ru(phenamine)Cl] (PF6). Yield : $94 \% .{ }^{1} \mathrm{H}$ NMR $\left(300 \mathrm{MHz}, \mathrm{CD}_{3} \mathrm{CN}\right): \delta$ (ppm) 9.63 (d, J = 5.3 Hz, 1H), $9.26(\mathrm{~d}, \mathrm{~J}=5.2 \mathrm{~Hz}, 1 \mathrm{H}), 8.73(\mathrm{~d}, \mathrm{~J}=8.4 \mathrm{~Hz}, 1 \mathrm{H}), 8.30$ (d, J = $8.4 \mathrm{~Hz}, 1 \mathrm{H}), 7.98$ (dd, J = 8.5, $5.3 \mathrm{~Hz}, 1 \mathrm{H}), 7.77$ (dd, J = 8.3, 5.2 Hz, 1H), 7.04 (s, 1H), 5.97 (s, 2H), 5.78 (s, 2H), 5.48 (s, 2H), 2.65 (hept., 1H), 2.05 (s, 3H), 0.97 (dd, J = 6.9, $3.1 \mathrm{~Hz}$, 6H). ESI-MS: m/z 465.6 [M-PF6 $^{+}$. 
[( $\eta^{6}$-p-cymene)Ru(phendione)Cl] (PF6). Yield: $91 \% .{ }^{1} \mathrm{H}$ NMR $\left(300 \mathrm{MHz}, \mathrm{CD}_{3} \mathrm{CN}\right): \delta$ (ppm) 9.69 (d, J = 5.3 Hz, 2H), 8.64 (d, J = 7.9 Hz, 2H), 7.98 (dd, J = 7.7, 5.7 Hz, 2H), 6.30 $(\mathrm{d}, \mathrm{J}=6.4 \mathrm{~Hz}, 2 \mathrm{H}), 6.06(\mathrm{~d}, \mathrm{~J}=6.0 \mathrm{~Hz}, 2 \mathrm{H}), 2.61$ (hept. , 1H), 2.22 (s, 3H), 0.96 (d, J = 6.8 $\mathrm{Hz}, 6 \mathrm{H})$. ESI-MS: m/z 481.2 [M-PF6 $^{+}$.

[( $\eta^{6}$-p-cymene)Ru(dppz)Cl] (PF6). Yield : $95 \%$. ${ }^{1} \mathrm{H}$ NMR (300 MHz, DMSO d6): $\delta$ (ppm) $10.01(\mathrm{~d}, \mathrm{~J}=5.2 \mathrm{~Hz}, 2 \mathrm{H}), 9.74(\mathrm{~d}, \mathrm{~J}=8.1 \mathrm{~Hz}, 2 \mathrm{H}), 8.49(\mathrm{dd}, \mathrm{J}=6.3,3.4 \mathrm{~Hz}, 2 \mathrm{H}), 8.31(\mathrm{dd}, \mathrm{J}$ $=8.1,5.4 \mathrm{~Hz}, 2 \mathrm{H}), 8.17(\mathrm{dd}, \mathrm{J}=6.4,3.4 \mathrm{~Hz}, 2 \mathrm{H}), 6.39(\mathrm{~d}, \mathrm{~J}=6.2 \mathrm{~Hz}, 2 \mathrm{H}), 6.16(\mathrm{~d}, \mathrm{~J}=6.2 \mathrm{~Hz}$, 2H), $2.79-2.62$ (hept., 1H), 2.21 (s, 3H), 1.00 (d, J = 6.8 Hz, 6H). ESI-MS: m/z 553.3 [M$\left.\mathrm{PF}_{6}\right]^{+}$.

General procedure for the synthesis of $\left[\left(\eta^{6}\right.\right.$-arene $\left.) R u\left(N^{\wedge} N\right) O T f\right](O T f)$ (arene $=$ bpy or $p$ cymene; $N^{\wedge} N=$ bpy, phen, phenamine):

Trifluoromethanesulfonic acid $(500 \mu \mathrm{L}, 5.65 \mathrm{mmol}, 100 \mathrm{eq})$ was carefully added to a suspension of $\left[\mathrm{Ru}\left(\eta^{6}\right.\right.$-arene $\left.)\left(\mathrm{N}^{\wedge} \mathrm{N}\right) \mathrm{Cl}\right]\left(\mathrm{PF}_{6}\right)(150 \mathrm{mg})$ in dichloromethane $(50 \mathrm{~mL})$. The reaction mixture was stirred at room temperature in the dark overnight. Addition of diethyl ether gave a yellowish precipitate, which was collected, washed thoroughly with diethyl ether and finally dried under vacuum.

[( $\eta^{6}$ - benzene)Ru(bpy)(OTf)](OTf). Yield: $91 \% .{ }^{1} \mathrm{H}$ NMR $\left(300 \mathrm{MHz}, \mathrm{CD}_{3} \mathrm{OD}\right): \delta(\mathrm{ppm})$ $9.81(\mathrm{~d}, \mathrm{~J}=5.5 \mathrm{~Hz}, 2 \mathrm{H}), 8.59(\mathrm{~d}, \mathrm{~J}=8.2 \mathrm{~Hz}, 2 \mathrm{H}), 8.39(\mathrm{t}, \mathrm{J}=7.9 \mathrm{~Hz}, 2 \mathrm{H}), 7.92$ (t, J = 6.6 Hz,

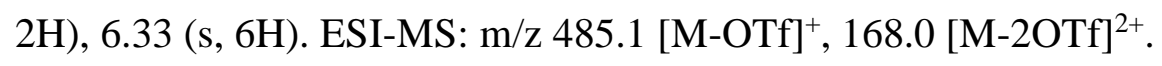

[( $\eta^{6}$-p-cymene)Ru(bpy)(OTf)](OTf). Yield: $94 \% .{ }^{1} \mathrm{H}$ NMR $\left(300 \mathrm{MHz}, \mathrm{CD}_{3} \mathrm{OD}\right): \delta(\mathrm{ppm})$ $9.82(\mathrm{~d}, \mathrm{~J}=5.7 \mathrm{~Hz}, 2 \mathrm{H}), 8.63(\mathrm{~d}, \mathrm{~J}=8.1 \mathrm{~Hz}, 2 \mathrm{H}), 8.42(\mathrm{t}, \mathrm{J}=8.0 \mathrm{~Hz}, 2 \mathrm{H}), 7.96(\mathrm{t}, \mathrm{J}=6.6 \mathrm{~Hz}$, 2H), $6.45(\mathrm{~d}, \mathrm{~J}=6.3 \mathrm{~Hz}, 2 \mathrm{H}), 6.23(\mathrm{~d}, \mathrm{~J}=6.3 \mathrm{~Hz}, 2 \mathrm{H}$ ), 2.57 (hept., J = $6.8 \mathrm{~Hz}, 1 \mathrm{H}$ ), 2.30 (s, $3 \mathrm{H}), 1.03(\mathrm{~d}, \mathrm{~J}=6.9 \mathrm{~Hz}, 6 \mathrm{H})$. ESI-MS: m/z 540.8 [M-OTf] $^{+}, 196.2$ [M-2OTf] $^{2+}$.

[( $\eta^{6}$ - benzene)Ru(phen)(OTf)](OTf). Yield: $93 \% .{ }^{1} \mathrm{H}$ NMR $\left(300 \mathrm{MHz}, \mathrm{CD}_{3} \mathrm{OD}\right): \delta(\mathrm{ppm})$ $10.15(\mathrm{~d}, \mathrm{~J}=5.3 \mathrm{~Hz}, 2 \mathrm{H}), 9.04(\mathrm{~d}, \mathrm{~J}=8.2 \mathrm{~Hz}, 2 \mathrm{H}), 8.46(\mathrm{~s}, 2 \mathrm{H}), 8.34(\mathrm{dd}, \mathrm{J}=8.2,5.1 \mathrm{~Hz}, 2 \mathrm{H})$,

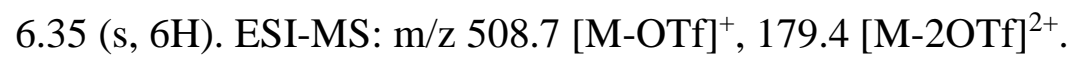

$\left[\left(\eta^{6}\right.\right.$-p-cymene)Ru(phen)(OTf)](OTf). Yield $91 \% .{ }^{1} \mathrm{H}$ NMR $\left(300 \mathrm{MHz}, \mathrm{CD}_{3} \mathrm{OD}\right): \delta(\mathrm{ppm})$ $10.19(\mathrm{~d}, \mathrm{~J}=5.3 \mathrm{~Hz}, 2 \mathrm{H}, 9.02(\mathrm{~d}, \mathrm{~J}=8.3 \mathrm{~Hz}, 2 \mathrm{H}), 8.35-8.20(\mathrm{~m}, 4 \mathrm{H}), 6.57$ (d, J = $6.4 \mathrm{~Hz}$, 2H), 6.37 (d, J = 6.4 Hz, 2H), 2.58 (hept., 1H), 2.29 (s, 3H), 0.97 (d, J = 6.9 Hz, 6H). ESI-MS: $\mathrm{m} / \mathrm{z} 564.9[\mathrm{M}-\mathrm{OTf}]^{+}, 207.4[\mathrm{M}-2 \mathrm{OTf}]^{2+}$. 
$\left[\left(\eta^{6}\right.\right.$ - benzene)Ru(phenamine)(OTf)](OTf). Yield: $92 \% .{ }^{1} \mathrm{H}$ NMR $\left(300 \mathrm{MHz}, \mathrm{CD}_{3} \mathrm{OD}\right): \delta$ (ppm)10.21 (d, J = 5.1 Hz, 1H), $9.45(\mathrm{~d}, \mathrm{~J}=5.3 \mathrm{~Hz}, 1 \mathrm{H}), 8.92(\mathrm{~d}, \mathrm{~J}=8.2 \mathrm{~Hz}, 1 \mathrm{H}), 8.53(\mathrm{~d}, \mathrm{~J}=$ $8.5 \mathrm{~Hz}, 1 \mathrm{H}), 8.26(\mathrm{dd}, \mathrm{J}=8.2,5.4 \mathrm{~Hz}, 1 \mathrm{H}), 8.02(\mathrm{dd}, \mathrm{J}=8.2,5.4 \mathrm{~Hz}, 1 \mathrm{H}), 7.16(\mathrm{~s}, 1 \mathrm{H}), 6.23$ $(\mathrm{s}, 6 \mathrm{H}), 5.62$ (s, 2H). ESI-MS: m/z $525.5[\mathrm{M}-\mathrm{OTf}]^{+}, 187.2[\mathrm{M}-2 \mathrm{OTf}]^{2+}$.

$\left[\left(\eta^{6}-p\right.\right.$-cymene)Ru(phenamine)(OTf)](OTf). Yield $93 \% .{ }^{1} \mathrm{H}$ NMR $\left(300 \mathrm{MHz}, \mathrm{CD}_{3} \mathrm{OD}\right): \delta$ (ppm)10.04 (d, J = 5.2 Hz, 1H), 9.47 (d, J = 5.3 Hz, 1H), 8.95 (d, J = 8.2 Hz, 1H), 8.52 (d, J = $8.1 \mathrm{~Hz}, 1 \mathrm{H}), 8.12(\mathrm{dd}, \mathrm{J}=8.4,5.4 \mathrm{~Hz}, 1 \mathrm{H}), 7.95(\mathrm{dd}, \mathrm{J}=8.1,5.2 \mathrm{~Hz}, 1 \mathrm{H}), 7.36(\mathrm{~s}, 1 \mathrm{H}), 6.19$ (s, 2H), 6.02 (s, 2H), 5.73 (s, 2H), 2.63 (s, 1H), 2.24 (s, 3H), 1.02 (dd, J = 6.9, 3.1 Hz, 6H).

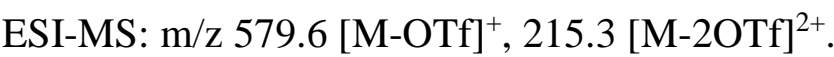

General Procedure for the synthesis of $\left[\mathrm{Ru}\left(4,4^{\prime}-\left(\mathrm{CH}_{2} \mathrm{PO}_{3} \mathrm{Et}_{2}\right)_{2}-b p y\right)_{2}\left(\mathrm{~N}^{\wedge} \mathrm{N}\right)\right]\left(\mathrm{PF}_{6}\right)_{2}$ by the organometallic route:

Method A (thermal conditions): A solution of $\left[\left(\eta^{6}\right.\right.$-arene $\left.) \mathrm{Ru}\left(\mathrm{N}^{\wedge} \mathrm{N}\right) \mathrm{Cl}\right]\left(\mathrm{PF}_{6}\right)(150 \mathrm{mg}, 1$ equivalent) and $4,4^{\prime}-\left(\mathrm{CH}_{2} \mathrm{PO}_{3} \mathrm{Et}_{2}\right)_{2}$-bpy (2 to 2.3 equivalents) in a mixture of water $(9 \mathrm{~mL})$ and 2-methoxyethanol $(36 \mathrm{~mL})$ was refluxed overnight. After cooling down to room temperature, $5 \mathrm{~mL}$ of a saturated $\mathrm{KPF}_{6}$ aqueous solution was added to the reaction mixture. Extraction with dichloromethane and removal of the organic solvent yield a reddish solid which was then subjected to chromatography on silica gel $\left(\mathrm{MeCN} /\right.$ aqueous $0.4 \mathrm{M} \mathrm{KNO}_{3}$, 80:20). After removal of $\mathrm{MeCN}$ under reduced pressure and addition of a saturated $\mathrm{KPF}_{6}$ aqueous solution $(5 \mathrm{~mL})$, the aqueous phase was further extracted $(3 \times 50 \mathrm{~mL})$ with dichloromethane and the organic phases washed with water. Evaporation of dichloromethane under reduced pressure gave a red-orange solid, which was collected and vacuum-dried overnight.

Method B (microwave conditions): A solution of $\left[\left(\eta^{6}\right.\right.$-arene $\left.) \mathrm{Ru}\left(\mathrm{N}^{\wedge} \mathrm{N}\right)(\mathrm{OTf})\right](\mathrm{OTf})(150 \mathrm{mg}, 1$ equivalent) and 4,4'-( $\left.\mathrm{CH}_{2} \mathrm{PO}_{3} \mathrm{Et}_{2}\right)_{2}$-bpy (2 equivalents) in ethanol $(10 \mathrm{~mL})$ was put in a sealed tube before being subjected to microwave irradiation $\left(150^{\circ} \mathrm{C}\right)$ for $20 \mathrm{~min}$. After cooling down to room temperature, $5 \mathrm{~mL}$ of a saturated $\mathrm{KPF}_{6}$ aqueous solution was added to the reaction mixture. Extraction with dichloromethane and removal of the organic solvent yield a reddish solid which was then subjected to chromatography on silica gel (MeCN / aqueous $0.4 \mathrm{M}$ $\mathrm{KNO}_{3}, 80: 20$ ). After removal of $\mathrm{MeCN}$ under reduced pressure and addition of a saturated $\mathrm{KPF}_{6}$ aqueous solution $(5 \mathrm{~mL})$, the aqueous phase was further extracted $(3 \times 50 \mathrm{~mL})$ with dichloromethane and the organic phases washed with water. Evaporation of dichloromethane 
under reduced pressure gave a red-orange solid, which was collected and vacuum-dried overnight.

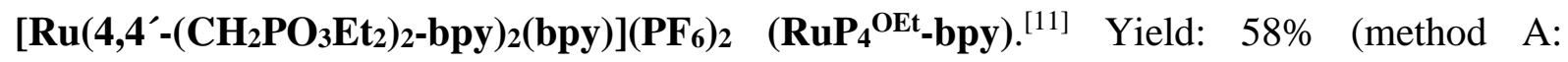
benzene); $58 \%$ (method B: benzene); 60\% (method B: p-cymene).

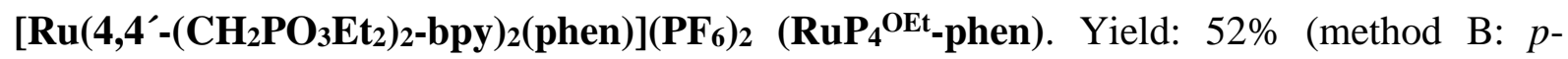
cymene). ${ }^{1} \mathrm{H}$ NMR $\left(300 \mathrm{MHz}, \mathrm{CD}_{3} \mathrm{CN}\right): \delta(\mathrm{ppm}) 8.62(\mathrm{~d}, \mathrm{~J}=8.2 \mathrm{~Hz}, 2 \mathrm{H}), 8.44(\mathrm{~d}, \mathrm{~J}=15.1$ $\mathrm{Hz}, 4 \mathrm{H}), 8.24(\mathrm{~s}, 2 \mathrm{H}), 8.06(\mathrm{~d}, \mathrm{~J}=5.2 \mathrm{~Hz}, 2 \mathrm{H}), 7.81-7.69(\mathrm{~m}, 4 \mathrm{H}), 7.43(\mathrm{~d}, \mathrm{~J}=5.8 \mathrm{~Hz}, 2 \mathrm{H})$, $7.39(\mathrm{~d}, \mathrm{~J}=5.7 \mathrm{~Hz}, 2 \mathrm{H}), 7.14(\mathrm{~d}, \mathrm{~J}=5.7 \mathrm{~Hz}, 2 \mathrm{H}), 4.11-3.88(\mathrm{~m}, 16 \mathrm{H}), 3.42(\mathrm{~d}, \mathrm{~J}=22.6 \mathrm{~Hz}$, 4H), $3.33(\mathrm{~d}, \mathrm{~J}=22.5 \mathrm{~Hz}, 4 \mathrm{H}), 1.25-1.03(\mathrm{~m}, 24 \mathrm{H})$. ESI-MS: m/z $597.1\left[\mathrm{M}-2 \mathrm{PF}_{6}\right]^{2+}$.

$\left[\mathrm{Ru}\left(4,4^{\prime}-\left(\mathrm{CH}_{2} \mathrm{PO}_{3} \mathrm{Et}_{2}\right)_{2}-\mathrm{bpy}_{2}\right)_{2}\left(\right.\right.$ phenNH$\left.\left._{2}\right)\right]\left(\mathrm{PF}_{6}\right)_{2}\left(\mathrm{RuP}_{4}{ }^{\mathrm{OEt}} \text {-phenNH}\right)_{2}$. Yield: $55 \%$ (method B: p-cymene). ${ }^{1} \mathrm{H}$ NMR (300 MHz, $\left.\mathrm{CD}_{3} \mathrm{CN}\right): \delta(\mathrm{ppm}) 8.61(\mathrm{~m}, \mathrm{~J}=8.5 \mathrm{~Hz}, 2 \mathrm{H}), 8.44(\mathrm{~s}, 2 \mathrm{H})$, 8.39 (s, 2H), $8.20(\mathrm{~d}, \mathrm{~J}=8.4 \mathrm{~Hz}, 1 \mathrm{H}), 8.02(\mathrm{~d}, \mathrm{~J}=5.1 \mathrm{~Hz}, 1 \mathrm{H}), 7.80-7.60(\mathrm{~m}, 4 \mathrm{H}), 7.54-$ $7.41(\mathrm{~m}, 3 \mathrm{H}), 7.37(\mathrm{~s}, 2 \mathrm{H}), 7.17(\mathrm{~s}, 2 \mathrm{H}), 5.57(\mathrm{~s}, 2 \mathrm{H}), 4.17-3.82(\mathrm{~m}, 16 \mathrm{H}), 3.55-3.16(\mathrm{~m}$, $8 \mathrm{H}), 1.32-0.99(\mathrm{~m}, 24 \mathrm{H})$. ESI-MS: m/z $604.3\left[\mathrm{M}-2 \mathrm{PF}_{6}\right]^{2+}$.

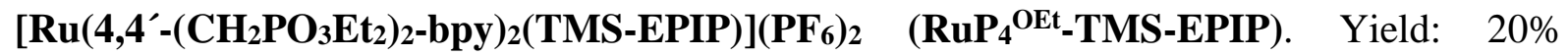
(method A: benzene; $2.3 \mathrm{eq}) .{ }^{1} \mathrm{H}$ NMR (300 MHz, $\mathrm{CD}_{3} \mathrm{CN}$ ): $\delta(\mathrm{ppm}) 9.04-8.91(\mathrm{~m}, 2 \mathrm{H})$, $8.43(\mathrm{~d}, J=14.7 \mathrm{~Hz}, 4 \mathrm{H}), 8.26(\mathrm{~d}, J=8.1 \mathrm{~Hz}, 2 \mathrm{H}), 7.99(\mathrm{~d}, J=4.2 \mathrm{~Hz}, 2 \mathrm{H}), 7.79-7.66(\mathrm{~m}$, $4 \mathrm{H}), 7.50(\mathrm{~d}, J=5.7 \mathrm{~Hz}, 2 \mathrm{H}), 7.40(\mathrm{dd}, J=5.4 \& 1.8 \mathrm{~Hz}, 4 \mathrm{H}), 7.15(\mathrm{~d}, J=5.7 \mathrm{~Hz}, 2 \mathrm{H}), 4.10-$ $3.89(\mathrm{~m}, 16 \mathrm{H}), 3.43(\mathrm{~d}, \mathrm{~J}=22.5 \mathrm{~Hz}, 4 \mathrm{H}), 3.33(\mathrm{~d}, \mathrm{~J}=22.5 \mathrm{~Hz}, 4 \mathrm{H}), 1.23-1.05(\mathrm{~m}, 24 \mathrm{H})$, $0.28(\mathrm{~s}, 9 \mathrm{H})$. ESI-MS: m/z $703.4\left[\mathrm{M}-2 \mathrm{PF}_{6}\right]^{2+}$.

General Procedure for the synthesis of $\left[\mathrm{Ru}\left(4,4^{\prime}-\left(\mathrm{CH}_{2} \mathrm{PO}_{3} \mathrm{Et}_{2}\right)_{2}-b p y\right)_{2}\left(\mathrm{~N}^{\wedge} \mathrm{N}\right)\right](\mathrm{PF})_{2}$ by the traditional approach ${ }^{[16]}\left(N^{\wedge} N\right.$ : phendione, dppz, epip-TMS, epip): A solution of commercially available $\mathrm{Ru}(\mathrm{DMSO})_{4} \mathrm{Cl}_{2}(420 \mathrm{mg}, 0.88 \mathrm{mmol})$ and 4,4'-( $\left.\mathrm{CH}_{2} \mathrm{PO}_{3} \mathrm{Et}_{2}\right)_{2}$-bpy (800 mg, 1.75 $\mathrm{mmol})$ in methanol $(100 \mathrm{~mL})$ was refluxed overnight under argon. Removal of the solvent and drying under vacuum yielded the dark-red highly hygroscopic intermediate $\left[R u\left(4,4^{\prime}-\right.\right.$ $\left(\mathrm{CH}_{2} \mathrm{PO}_{3} \mathrm{Et}_{2}\right)_{2}$-bpy $\left.)_{2} \mathrm{Cl}_{\mathrm{x}}(\mathrm{DMSO})_{2-\mathrm{x}}\right] \mathrm{Cl}_{2-\mathrm{x}}$. A solution of crude $\left[\mathrm{Ru}\left(4,4^{\prime}-\left(\mathrm{CH}_{2} \mathrm{PO}_{3} \mathrm{Et}_{2}\right)_{2-}\right.\right.$ bpy) $\left.{ }_{2} \mathrm{Cl}_{\mathrm{x}}(\mathrm{DMSO})_{2-\mathrm{x}}\right] \mathrm{Cl}_{2-\mathrm{x}}$ (1 equivalent, using an average molecular weight) and $\mathrm{N}^{\wedge} \mathrm{N}$ (1 to 1.5 equivalent) in a water/ethanol (1:3) mixture was refluxed overnight. After cooling down to room temperature, $5 \mathrm{~mL}$ of a saturated $\mathrm{KPF}_{6}$ aqueous solution was added to the reaction mixture. Extraction with dichloromethane and removal of the organic solvent yield a crude reddish solid. After purification by flash chromatography on silica gel (MeCN/aqueous $\mathrm{KNO}_{3}$ (0.4 M), 80:20), MeCN was removed under reduced pressure and a saturated $\mathrm{KPF}_{6}$ aqueous 
solution $(5 \mathrm{~mL})$ added. The aqueous phase was further extracted $(3 \times 50 \mathrm{~mL})$ with dichloromethane and the organic phases washed with water. Evaporation of dichloromethane under reduced pressure gave red-orange solids, which were collected and vacuum-dried overnight.

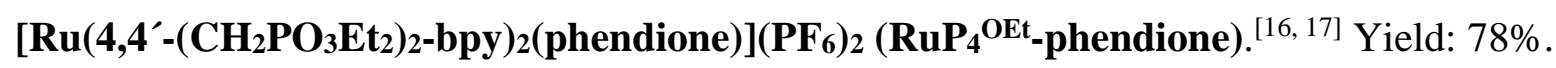

$\left[\mathbf{R u}\left(4,4^{\prime}-\left(\mathrm{CH}_{2} \mathrm{PO}_{3} \mathrm{Et}_{2}\right)_{2}-\mathrm{bpy}\right)_{2}(\mathbf{d p p z})\right]\left(\mathrm{PF}_{6}\right)_{2}\left(\mathrm{RuP}_{4}{ }^{\mathrm{OEt}} \text {-dppz }\right)^{[11]}$ Yield: $55 \%$.

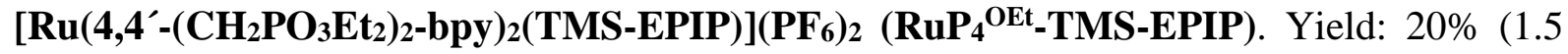
eq of TMS-EPIP ligand).

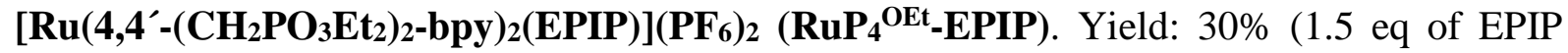
ligand). ${ }^{1} \mathrm{H}$ NMR $\left(300 \mathrm{MHz}, \mathrm{CD}_{3} \mathrm{CN}\right): \delta(\mathrm{ppm}) 9.09$ (d, $\left.J=8.5 \mathrm{~Hz}, 1 \mathrm{H}\right), 8.87(\mathrm{~d}, J=8.1 \mathrm{~Hz}$, $1 \mathrm{H}), 8.42(\mathrm{~d}, J=15.4 \mathrm{~Hz}, 4 \mathrm{H}), 8.28(\mathrm{~d}, J=8.5,2 \mathrm{H}), 8.00(\mathrm{~d}, J=5.1 \mathrm{~Hz}, 2 \mathrm{H}), 7.81-7.74(\mathrm{~m}$, $6 \mathrm{H}), 7.49(\mathrm{t}, J=6.0 \mathrm{~Hz}, 2 \mathrm{H}), 7.40(\mathrm{~d}, J=5.4 \mathrm{~Hz}, 2 \mathrm{H}), 7.15$ (s broad, 2H), $4.10-3.88$ (m, $16 \mathrm{H}), 3.60(\mathrm{~s}, 1 \mathrm{H}), 3.42(\mathrm{~d}, J=22.6,4 \mathrm{H}), 3.32(\mathrm{~d}, J=22.6,4 \mathrm{H}), 1.23-1.05(\mathrm{~m}, 24 \mathrm{H})$. ESIMS: $\mathrm{m} / \mathrm{z} 667.3\left[\mathrm{M}-2 \mathrm{PF}_{6}\right]^{2+}$.

Supporting Information. ${ }^{1} \mathrm{H}$ NMR spectra, UV-vis absorption spectra and cyclic voltammograms for all new complexes.

\section{Acknowledgements}

Colette Lebrun (CEA/DRF/INAC/SyMMES) is acknowledged for the ESI-MS measurements. This work was supported by the Labex program ARCANE (ANR-11-LABX-0003-01), the graduate school in Chemistry, Biology and Health of Univ. Grenoble Alpes (CBH-EUR-GS, ANR-17-EURE-0003), the European Research Council under the European Union's Seventh Framework Program FP/2007-2013 (ERC Grant Agreement n.306398).

\section{Bibliography}

[1] P. Xu, N. S. McCool, T. E. Mallouk, Nano Today 2017, 14, 42-58.

[2] M. K. Brennaman, R. J. Dillon, L. Alibabaei, M. K. Gish, C. J. Dares, D. L. Ashford, R. L. House, G. J. Meyer, J. M. Papanikolas, T. J. Meyer, J. Am. Chem. Soc. 2016, 138, 1308513102.

[3] Z. Yu, F. Li, L. Sun, Energy Environ. Sci. 2015, 8, 760-775.

[4] S. Berardi, S. Drouet, L. Francas, C. Gimbert-Surinach, M. Guttentag, C. Richmond, T. Stoll, A. Llobet, Chem. Soc. Rev. 2014, 43, 7501-7519.

[5] A. Hagfeldt, G. Boschloo, L. Sun, L. Kloo, H. Pettersson, Chem. Rev. 2010, 110, 6595-6663.

[6] C. Queffelec, M. Petit, P. Janvier, D. A. Knight, B. Bujoli, Chem. Rev. 2012, 112, 3777-3807.

[7] P. H. Mutin, G. Guerrero, A. Vioux, J. Mater. Chem. 2005, 15, 3761-3768.

[8] L. Zhang, J. M. Cole, ACS Appl. Mater. Interfaces 2015, 7, 3427-3455. 
[9] I. Gillaizeau-Gauthier, F. Odobel, M. Alebbi, R. Argazzi, E. Costa, C. A. Bignozzi, P. Qu, G. J. Meyer, Inorg. Chem. 2001, 40, 6073-6079.

[10] K. Hanson, M. K. Brennaman, H. Luo, C. R. K. Glasson, J. J. Concepcion, W. Song, T. J. Meyer, ACS Appl. Mater. Interfaces 2012, 4, 1462-1469.

[11] N. Queyriaux, R. A. Wahyuono, J. Fize, C. Gablin, M. Wächtler, E. Martinez, D. Léonard, B. Dietzek, V. Artero, M. Chavarot-Kerlidou, J. Phys. Chem. C 2017, 121, 5891-5904.

[12] Y. Pellegrin, L. Le Pleux, E. Blart, A. Renaud, B. Chavillon, N. Szuwarski, M. Boujtita, L. Cario, S. Jobic, D. Jacquemin, F. Odobel, J. Photochem. Photobiol. A: Chemistry 2011, 219, 235-242.

[13] A. Zaban, S. Ferrere, B. A. Gregg, J. Phys. Chem. B 1998, 102, 452-460.

[14] G. Will, G. Boschloo, S. N. Rao, D. Fitzmaurice, J. Phys. Chem. B 1999, 103, 8067-8079.

[15] J. Sotomayor, G. Will, D. Fitzmaurice, J. Mater. Chem. 2000, 10, 685-692.

[16] M. Braumuller, M. Schulz, D. Sorsche, M. Pfeffer, M. Schaub, J. Popp, B.-W. Park, A. Hagfeldt, B. Dietzek, S. Rau, Dalton Trans. 2015, 44, 5577-5586.

[17] M. Braumuller, M. Schulz, M. Staniszewska, D. Sorsche, M. Wunderlin, J. Popp, J. Guthmuller, B. Dietzek, S. Rau, Dalton Trans. 2016, 45, 9216-9228.

[18] S. Caramori, V. Cristino, R. Argazzi, L. Meda, C. A. Bignozzi, Inorg. Chem. 2010, 49, 33203328.

[19] D. L. Ashford, W. Song, J. J. Concepcion, C. R. K. Glasson, M. K. Brennaman, M. R. Norris, Z. Fang, J. L. Templeton, T. J. Meyer, J. Am. Chem. Soc. 2012, 134, 19189-19198.

[20] M. R. Norris, J. J. Concepcion, C. R. K. Glasson, Z. Fang, A. M. Lapides, D. L. Ashford, J. L. Templeton, T. J. Meyer, Inorg. Chem. 2013, 52, 12492-12501.

[21] N. Queyriaux, E. S. Andreiadis, S. Torelli, J. Pecaut, B. S. Veldkamp, E. A. Margulies, M. R. Wasielewski, M. Chavarot-Kerlidou, V. Artero, Faraday Discuss. 2017, 198, 251-261.

[22] C. Menéndez, D. Morales, J. Pérez, V. Riera, D. Miguel, Organometallics 2001, 20, 27752781.

[23] C. O. Kappe, Angew. Chem. Int. Ed. 2004, 43, 6250-6284.

[24] S. Rau, B. Schäfer, A. Grüßing, S. Schebesta, K. Lamm, J. Vieth, H. Görls, D. Walther, M. Rudolph, U. W. Grummt, E. Birkner, Inorg. Chim. Acta 2004, 357, 4496-4503.

[25] H. Zabri, I. Gillaizeau, C. A. Bignozzi, S. Caramori, M.-F. Charlot, J. Cano-Boquera, F. Odobel, Inorg. Chem. 2003, 42, 6655-6666.

[26] E. Sabatani, H. D. Nikol, H. B. Gray, F. C. Anson, J. Am. Chem. Soc. 1996, 118, 1158-1163.

[27] M. Montalti, S. Wadhwa, W. Y. Kim, R. A. Kipp, R. H. Schmehl, Inorg. Chem. 2000, 39, 7684.

[28] J. Fees, W. Kaim, M. Moscherosch, W. Matheis, J. Klima, M. Krejcik, S. Zalis, Inorg. Chem. 1993, 32, 166-174.

[29] E. Amouyal, A. Homsi, J.-C. Chambron, J.-P. Sauvage, J. Chem. Soc., Dalton Trans. 1990, 1841-1845.

[30] J. Ettedgui, R. Neumann, J. Am. Chem. Soc. 2009, 131, 4-5.

[31] S. Ramachandra, K. C. Schuermann, F. Edafe, P. Belser, C. A. Nijhuis, W. F. Reus, G. M. Whitesides, L. De Cola, Inorg. Chem. 2011, 50, 1581-1591.

[32] M. A. Bennett, A. K. Smith, J. Chem. Soc., Dalton Trans. 1974, 233-241. 